\title{
Mesozoic volcanogenic massive sulfide (VMS) deposits in Mexico
}

Antoni Camprubíi, ${ }^{\mathrm{a}, *}$, Eduardo González-Partida ${ }^{\mathrm{b}}$, Lisard Torróc ${ }^{\mathrm{c}}$, Pura Alfonso ${ }^{\mathrm{d}}$, Carles

Canet $^{\mathrm{e}}$, Miguel A. Miranda-Gasca ${ }^{\mathrm{f}}$, Michelangelo Martini ${ }^{1}$, Francisco González-Sánchez ${ }^{\mathrm{g}}$

${ }^{a}$ Instituto de Geología, Universidad Nacional Autónoma de México. Ciudad Universitaria, 04510 México, D.F., Mexico

${ }^{b}$ Centro de Geociencias, Universidad Nacional Autónoma de México. Boulevard Juriquilla 3001, 76230 Juriquilla, Querétaro, Mexico

${ }^{c}$ Departament de Cristal-lografia, Mineralogia i Dipòsits Minerals, Facultat de Geologia, Universitat de Barcelona. Carrer de Martí i Franquès s/n, 08028 Barcelona, Catalonia, Spain

d Departament d'Enginyeria Minera i Recursos Naturals, Universitat Politècnica de Catalunya. Av. de les Bases de Manresa 61-73, 08242 Manresa, Catalonia, Spain

${ }^{e}$ Instituto de Geofísica, Universidad Nacional Autónoma de México. Ciudad Universitaria, 04510 México, D.F., Mexico

${ }^{f}$ Minas GRC S.A. de C.V.-Cloncurry Metals Ltd. Andador 101 L17 M306, Col. Ce. Chapultepec, 62398 Cuernavaca, Morelos, Mexico

${ }^{g}$ Instituto Tecnológico Superior de Tacámbaro. Av. Tecnológico 201, Zona El Gigante, 61650 Tacámbaro, Michoacán, Mexico

* corresponding author: camprubitaga@gmail.com 


\section{ABSTRACT}

Volcanogenic massive sulfide (VMS) deposits are the most conspicuous type of deposits that formed during the Mesozoic inMexico.ManyMexicanVMS deposits display "classical" Kuroko-typemineral zonation and structure, and some of them, as Cuale and La Minita formed in shallowsubmarine environments. Themost prospective time window for the formation of VMS deposits in Mexico comprises the Late Jurassic and the Early Cretaceous. VMS stopped forming during the progressive continentalization of Mexico, since its metallotectonic processes (dominated by extensive tectonics) changed givingway to compression during the late Early Cretaceous; newVMS deposits did not form until after the opening of the Gulf of California.

MesozoicVMS deposits inMexico occur in submarine volcano-sedimentary sequences that deposited essentially in association with back-arc basins (now found roughly along the boundaries between tectonostratigraphic terranes) or within juvenile and slightly evolved arcs (at the internal parts of the terranes), while few others occur on the epicontinental seafloor and hinterlands of eastern Mexico. VMS deposits are especially abundant in the Guerrero composite terrane, and are also present in the Alisitos and Parral terranes. However, new evidence referred in this paper indicate the western continental edge of the cratonic block of Oaxaquia as a promising, new prospective region for VMS deposits. Interestingly, no VMS deposits are found in the northern part of the Guerrero composite terrane despite the occurrence of marine volcano-sedimentary sequences similar to those in the south; such absence can be related to differential extensional unroofing, much larger in the southern part of the Guerrero composite terrane than in the northern part.Many VMS deposits occur along or close to terrane boundaries, especially around the Guerrero composite terrane. This distribution reflects the association between VMS deposits and back-arc basins, which represented the frontal part of terranes or sub-terranes that were ultimately accreted to the Oaxaquia cratonic block. As a consequence, VMS deposits usually display strong deformation and thrusting, and their mineral and compositional zonation can be found overturned. Due to such common association between these deposits and terrane boundaries that reactivated during the Cenozoic, VMS deposits are especially susceptible to overprinting by later metallogenic processes, unrelated to VMS-producing 
environments. This susceptibility may be held accountable for the complexmineral associations found in the Francisco I.Madero deposit.

The inclusion fluids in the Cuale, LaMinita, El Rubí, Tizapa and CampoMorado deposits have salinities that range from 2.5 to $20.0 \mathrm{wt} . \% \mathrm{NaCl}$ equiv. and temperatures of homogenization from $110^{\circ}$ to $420{ }^{\circ} \mathrm{C}$, although a particular fluid inclusion assemblage (with daughter halite and sylvite) from a stockwork at the Tizapa deposit ranged salinities from 39.7 to 64.7 wt.\% $\mathrm{NaCl}$ and from 35.9 to 43.5 wt.\% $\mathrm{KCl}$, and temperatures of homogenization from $440^{\circ}$ to $550{ }^{\circ} \mathrm{C}$. The general characteristics listed above may account for mineralizing fluids from magmatic, marine, and modified marine sources. The entrainment of cool and oxidizing seawater within upwelling fluids increased as the paleohydrothermal systems waned. The waning stages are normally represented by bariterich mineralizations and, in the case of the La Minita deposit, this notoriously outlasted by Mn oxide mineralization

that reflects even more oxidizing conditions. A similar evolution is deduced in Cuale, which is the only known Mesozoic VMS deposit in Mexico that formed in a shallowsubmarine environment together with La Minita. The shallower the formation of VMS deposits is, themore quickly mineralizing fluids evolve into highly oxidized end-members, once the paleohydrothermal systems cooled down. The extremely high-salinity and hot inclusion

\section{Introduction}

Volcanogenic massive sulfide deposits (VMS) constitute the most abundant type of Mesozoic ore deposits inMexico, especially regarding pre-Cenomanian deposits. They occur along the Pacific margin, from Baja California to the Guerrero State, and in Chihuahua (Fig. 1). The overwhelming majority of VMS deposits in Mexico are classified as Kuroko-type deposits (e.g., Charoy and González-Partida, 1984). The vast majority of VMS deposits in Mexico belong to the $\mathrm{Zn}-\mathrm{Pb}-\mathrm{Cu}$ or $\mathrm{Zn}-\mathrm{Cu}$ metal associations of Large (1992) (Fig. 2). They formed in association with either calc-alkaline, tholeiitic or alkaline volcanic rocks (González-Partida, 1993), although the time and space distribution of such 
rock types is still poorly known. These deposits are found in submarine volcanosedimentary rock assemblages of various compositions that were widespread during the Cretaceous in southwestern Mexico, mostly in the terranes on the Pacific side. Some VMS deposits formed in back-arc settings, within juvenile and slightly evolved submarine arcs, while few others on the epicontinental seafloor of eastern Mexico (Mortensen et al., 2008). The known or estimated ages of VMS deposits in Mexico mostly range from Late Jurassic to Early Cretaceous (Fig. 1), being virtually restricted to the Mesozoic, set aside the oldest

VMS known to date in Mexico, the Carboniferous Teziutlán deposit in Puebla (the possible sole example of the Besshi type in Mexico; see Camprubí, 2009, and references therein), the Cerro Dolores deposit (hosted by the Permo-Triassic Petlalcingo Group in the Mixteco terrane; Ramírez-Espinoza, 2001; Keppie et al., 2006), themodern deposits in the slow-spreading Gulf of California (e.g., the Guaymas basin) and those along the East Pacific Rise. Even though VMS deposits in northern Mexico are poorly known, some authors (e.g., Miranda-Gasca, 2003) ascribed the Cretaceous $\mathrm{Zn}-\mathrm{Pb}-\mathrm{Cu}-\mathrm{Ag}-\mathrm{Au}$ deposits at Valle de Los Olivos in Chihuahua to the Kuroko-type. Interestingly enough, many VMS deposits occur along or close to terrane boundaries, especially around the Guerrero composite terrane, but also in the Parral terrane next to its boundary with the Caborca terrane (Valle de los Olivos), in the cratonic block of Oaxaquia next to the Guerrero composite terrane (San Ignacio), and in the Alisitos arc terrane close to the Palezoic terranes of eastern Baja California (La Prosperidad and Calmallí).

VMS deposits in the Guerrero composite terrane occur in two distinct belts: a coastal belt (Cuale-Bramador, La Minita-Sapo Negro, Arroyo Seco, etc.), and a belt inland, by the eastern boundary of this terrane (San Nicolás-El Salvador, the deposits in the Guanajuato ranges, Tizapa-Santa Rosa, Tlanilpa-Azuláquez, Rey de Plata, Campo Morado-Suriana, etc.), which constitutes the region where such deposits are more abundant. As indicated by Mortensen et al. (2008), these belts are dominantly associated with volcanosedimentary rock assemblages of the bimodal-felsic type (coastal belt) or of the bimodal-siliciclastic type (eastern belt). According to the current tectonomagmatic models concerning the Arperos Basin, which bounded the eastern part of the Guerrero composite terrane, this basin is likely to be due to a paraautochthonous scenario in which the Guerrero composite terrane would constitute a piece of North America rather than an exotic terrane (Martini et 
al., 2012) girdled by VMS deposits. Or, in the words of Mortensen et al. (2008), the Guerrero composite terrane constitutes a west-facing continental margin arc that was built on mainly oceanic crust along the western margin of nuclear Mexico [sic]. According to such models, VMS deposits near the eastern boundary of the Guerrero composite terrane can be hypothesized as deposits formed in arc/back-arc environments, although only the San Nicolás-El Salvador deposits have been satisfactorily identified as formed in a backarc setting (Mortensen et al., 2008).

Most of the deposits locatedwithin or along the limit of the Guerrero composite terrane underwent dynamo-thermal and/or contact-thermal metamorphism in the greenschist facies and variable grades of deformation (e.g., strong deformation during the D1 and D2 phases at Rey de Plata; Monter-Ramírez and Zavala-Esquivel, 2011), to the point that the mineralized bodies were commonly thrust and overturned (Fig. 3). Such deformation and metamorphism probably occurred between Late Cretaceous and Paleocene, although the timing of deformation in the region needs to be further addressed in future research.

Mesozoic VMS deposits occur preferentially in the Guerrero composite terrane and are described belowby their terrane bearing. For further details about the structure and mineralogy of VMS deposits in Mexico, see Miranda-Gasca (1995, 2000).

\subsection{Deposits in the Teloloapan terrane}

Four main clusters of VMS deposits occur in the Teloloapan terrane: Rey de Plata, CampoMorado-Suriana, Tlanilpa-Azulaquez, and Tizapa-Esmeralda-Santa Rosa. Such terrane is constituted by volcaniclastic rocks, turbidites, reefal limestones, and calc-alkaline andesites, basalts and rhyolites. Their ages were constrained bymeans of their fossil content as Hauterivian-Aptian and Aptian-Albian (Talavera-Mendoza et al., 2007), and by U-Pb dating as Late Jurassic-Early Cretaceous (Mortensen et al., 2008, and references therein). At the Rey de Plata and Campo Morado-Suriana deposits, volcaniclatic rocks are mainly rhyolitic to andesitic (Miranda-Gasca, 1995) and dated between 137 and $154 \mathrm{Ma}$ (U-Pb; Mortensen et al., 2008). They are covered by carbonate rocks that were stratigraphically determined to be Albian in Campo Morado by Lorinczi and Miranda (1978). Spilitized pillow-lavas, and tuffs and rhyolites metamorphosed into sericite schists host VMS deposits 
at Rey de Plata (González-Partida, 1993; Miranda-Gasca et al., 2001). Rhys et al. (2000) dated a dioritic intrusive in the 'parental' rhyolitic and dioritic sequence of TlanilpaAzulaquez at $138.7 \mathrm{Ma}(\mathrm{U}-\mathrm{Pb})$.

\subsection{Deposits in the Zihuatanejo and Alisitos terranes}

The Zihuatanejo terrane contains fivemain clusters ofVMS deposits: (1) the Cuale and Talpa de Allende cluster includes the El Bramador, La América, El Rubí, and El Desmoronado (also named Amaltea) deposits, (2) the La Minita cluster includes the La Codiciada, La Blanca and Sapo Negro deposits, besides the eponymous main deposits, (3) the Zacatecas cluster includes the San Nicolás-El Salvador and the Francisco I. Madero deposits, and (4) the Copper King and associated occurrences are found in the Las OllasPapanoa-Camalotito ultramafic-mafic complex. As already noticed by Miranda-Gasca (1995, 2000), the Cu-type Copper King deposit may be of the Cyprus type, as the sole example of such type ever mentioned in Mexico.

At the Cuale deposits, volcaniclastic rocks overlie pelitic schists and are essentially chloritized dacitic to rhyolitic tuffs, associatedwith rhyolitic porphyry domes and interbedded with tuffaceous sandstones (González-Partida, 1993). A shallow submarine environment is convincingly invoked (Bissig et al., 2008). U-Pb dating of zircons in that deposit yielded ages between 162 and 155 Ma (Bissig et al., 2008). This represents the oldest (Middle-Late Jurassic) VMS deposit within the Guerrero composite terrane.

At the LaMinita deposit, pyroclasticswere deposited alongwith rudist reef deposits and fossil-rich shales, aged Albian (González-Partida, 1981, 1985; González-Partida andTorresRodríguez, 1988). Such rock ensemble emphasizes the volcano-sedimentary character of the deposits and their formation in a shallow submarine environment.

The regional rocks in the Copper King area belong to an ultramafic-mafic complex that has been described to have formed in an intraoceanic arc (Ortiz-Hernández et al., 2006) dated at $112 \mathrm{Ma}$ (Talavera-Mendoza, 2001) and was emplaced onto the continent, probably as part of the Arteaga accretionary prism. The basic submarine volcanism in the above regions has alkaline affinity whereas intermediate to acid volcanism (andesites, dacites, rhyolites) is essentially calc-alkaline (González-Partida, 1993; Tardy et al., 1994). 
The largest VMS deposits in Mexico (or assumed VMS) are San Nicolás and Francisco I. Madero (both in Zacatecas) occur in the northern Zihuatanejo terrane, with tonnage and average grades of $99.5 \mathrm{Mt}$ at $24 \mathrm{~g} / \mathrm{t} \mathrm{Ag}, 0.41 \mathrm{~g} / \mathrm{t} \mathrm{Au}, 0.15 \% \mathrm{~Pb}, 1.64 \% \mathrm{Zn}$ and $1.36 \% \mathrm{Cu}$, and $\mathrm{N} 40 \mathrm{Mt}$ at $31 \mathrm{~g} / \mathrm{t} \mathrm{Ag,} 0.9 \% \mathrm{~Pb}, 5.0 \% \mathrm{Zn}$ and $0.11 \% \mathrm{Cu}$, respectively. Other deposits from the same region are El Salvador and Dos Hermanas in Zacatecas. Themassive sulfides at San Nicolás are associated with calc-alkaline bimodal basic to acid volcanism, and are dated between 147 and $150 \mathrm{Ma}(\mathrm{U}-\mathrm{Pb}$; Mortensen et al., 2008).

On the other hand, the Alisitos arc in the Baja California Peninsula correlates with the Zihuatanejo terrane and is considered by Almazán-Vázquez (1988a,b) as a calc-alkaline island arc that formed close to the western margin of the North America plate. The Alisitos arc includes the poorly known Calmallí and Prosperidad deposits.

\subsection{Deposits in the Guanajuato terrane (?)}

Several deposits have been traditionally included in the Guanajuato terrane, namely San Ignacio (also named Los Mexicanos), El Guapillo (also named Yolanda), La Virgen (Miranda-Gasca, 1995), El Gordo, and Los Gavilanes (Hall and Gómez-Torres, 2000b,c). However, newevidence indicate that at least some of them actually formed at the continental margin of Oaxaquia (Sierra Madre terrane). In fact, the San Ignacio deposit is hosted by $145 \mathrm{Ma}$ felsic volcanic rocks that are interbedded with sandstones, phyllites, and micritic debris flows of the Esperanza and Valenciana formations (Martini et al., 2011). Provenance analysis, supported by U-Pb dating of detrital zircons, indicates that the clastic rocks of this succession were fed by sources from the Late Mesozoic mainland of centralMexico, represented by Oaxaquia and its basement (Martini et al., 2011). This provenance is also supported by the lack of feldspar and Middle to Late Jurassic zircons in the arenites of the Esperanza Formation, which indicates that these rocks were deposited relatively far fromthe sedimentary influence of the arc successions of the Guerrero composite terrane (Martini et al., 2011).

The El Gordo and Los Gavilanes deposits are hosted by rhyolites, and rhyolitic tuffs and flows that overlie limestones and shales (Hall and Gómez-Torres, 2000b,c). In Guanajuato, Tardy et al. (1994) described calc-alkaline to shoshonitic affinities, with high 
$\mathrm{Zr}, \mathrm{Nb}$, and Y contents, for rocks that correlate with the VMS deposit-bearing stratigraphic interval. Further, the Arperos gabbros have a large range of $206 \mathrm{~Pb} / 204 \mathrm{~Pb}$ and $208 \mathrm{~Pb} / 204 \mathrm{~Pb}$ ratios, and Lapierre et al. (2000) suggested that these were derived from a ridge-centered or a near-ridge hot spot. The VMS mineralization in Guanajuato (e.g., the San Ignacio mine; Martínez-Reyes et al., 1995) has a rather disseminated character; the host pillow lavas are basaltic in composition, are intercalated with tuffs, and correspond to arc tholeiites with low TiO2, K2O, Zr and LREE, and highNb contents (Ortiz-Hernández et al., 1992). These pillow lavas were dated at 146 Ma near the town of León (U-Pb; Mortensen et al., 2008).

\subsection{Deposits in the Arcelia terrane}

The Arcelia terrane probably represents a back-arc basin that evolved between the Teloloapan and Zihuatanejo terranes, whereas the Arperos area represents the most evolved (central) part of the rift basin, and includes exposures of basic rocks and scattered VMS deposits. Such rocks were formed on the continental crust (see, among others, GonzálezPartida and Torres-Rodríguez, 1988; Tardy et al., 1994; Goldhammer and Johnson, 2001), similarly to the Andean-type arc described by Busby-Spera (1988) for the Early Mesozoic continental arc in the southwestern USA.

\section{Structure, morphology andmineralogy}

\subsection{Cuale, Jalisco}

Kuroko-like ore zonation occurs in Cuale,with yellowand black ores, and stockwork mineralization in a rhyolitic dome (Fig. 4). There are also ores reworked by seafloor currents, and chemical sediments (i.e. exhalites) that deposited away from the emission centers. This district comprises no less than 22 mineralized bodies with significant polymetallic mineralization that appear to be restricted to a short period of time (Hall and

Gómez-Torres, 2000a; Bissig et al., 2008). All the deposits formed within a single stratigraphic horizon and were covered by chert horizons containing some $\mathrm{Au}$ and $\mathrm{Ag}$ 
mineralization, which are interpreted as exhalites. Such deposits are also found in the El Rubí deposit in the Talpa de Allende district.

Stockworks contain sphalerite, chalcopyrite, galena, subordinate native silver or gold, and pyrite. Mineralized lenses in this district can be described as classic Kuroko-type yellow ore and black ore associations (Hall and Gómez-Torres, 2000a; Bissig et al., 2008). Yellow ore is constituted by dominant chalcopyrite and pyrite, with subordinate galena, sphalerite, barite and native silver or gold. Black ore consists of an early association of galena, sphalerite, pyrrhotite, pyrite, and cubanite, and a late association of pyrite, tetrahedrite-tennantite, stromeyerite, and native silver, with barite, anhydrite and calcite as gangue minerals. Additionally, there are later barite- and hematite-rich mantos (stratabound replacements). Minor minerals within the above assemblages include enargite, geocronite, proustite-pyrargyrite, and stannite. The deepest parts of orebodies show thick $(\sim 5 \mathrm{~m})$ chlorite-rich halos, whereas stockworks are enveloped by phyllic and propylitic alteration assemblages. Similar structures and alteration assemblages are found in the El Rubí deposit as well, which are interpreted here as representative of major channelways for upwelling hydrothermal fluids.

\subsection{Francisco I. Madero, Zacatecas}

The genesis of the $\mathrm{Zn}-\mathrm{Cu}-\mathrm{Pb}-(\mathrm{Ag})$ Francisco I. Madero deposits has been controversial since its discovery. Many orebodies are stratabound while others could be stratiform, and are hosted by Mesozoic marine black shales and carbonate rocks (see Figure 2 in Canet et al., 2009) that deposited in a back-arc environment. The only intrusive rocks observable near the ores are a few Cenozoic dikes, even though geophysical surveys in this area seemingly suggest the occurrence of a deep-seated intrusive (González-Villalvaso and López-Soto, 2009).

Escalona-Alcázar et al. (2009) described the environment for the deposition of the Late Jurassic (?) to Early Cretaceous Zacatecas and Las Pilas Formations as occurring on the inland margin of an oceanic arc, on the edge of a back-arc basin, hence the likeliness for the occurrence of Kuroko-type deposits in the region. In fact, Escalona-Alcázar et al. (2009)mentioned the occurrence of synformational hydrothermal venting in the volcano- 
sedimentary arc-related rocks, but such venting probably occurred earlier than the Madero deposits. U-Pb ages in zircons from the Zacatecas region peak at 132-160 Ma, whereas zircons in the Las Pilas Volcano-sedimentary Complex, which hosts the Madero deposits, yielded U-Pb ages at 133-141 Ma (Escalona-Alcázar et al., 2009).

Syngenetic submarine exhalative models, either sedimentary exhalative (SEDEX) or volcanogenic (VMS), have been suggested for the formation of the Madero deposits (e.g., Góngora-Flemate, 2001; González-Villalvaso and López-Soto, 2009), although a SEDEX model was readily ruled out by Canet et al. (2009). Also, the predominance of calc-silicate assemblages and replacement textures that developed selectively along limestone beds, and the absence of exhalites or underlying structures that would be attributable to feeder zones, suggest a distal skarn model for ore formation (Canet et al., 2009). Furthermore, lead isotope studies in the Madero ores suggest that this deposit is Cenozoic in age, and thus it is, at least in part, epigenetic and related to continental arc magmatism(Mortensen et al., 2008). The possible overlapping of skarn on VMS mineralization is illustrated by two distinctive assemblages of massive sulfides: (1) thinly laminated massive sulfides with finegrained pyrrhotite, pyrite and sphalerite, which constitute the ore assemblages that better resemble VMS-type mineralization, and (2) later coarse-grained massive ore assemblages that are mostly composed by pyrrhotite, sphalerite and galena (see Figure 3 in Canet et al., 2009), which occur generally in the vicinity of dikes and are associated with late epithermal calcite-quartz veins (plausible skarn-type stages of mineralization). $\mathrm{Zn}-\mathrm{Pb}$ orebodies are associated with host rocks that are largely altered to chlorite and epidote. Other alteration/skarn assemblages include manganoan hedenbergite, tremolite-actinolite, stilpnomelane and andradite, associated with pyrite and magnetite (Canet et al., 2009).

Massive sulfides contain pyrite, pyrrhotite, sphalerite, chalcopyrite, arsenopyrite, and galena. Late calcite-quartz veins, possibly associated with the retrograde skarn stages, contain chlorite, dolomite, fluorite, hessite, matildite, tetradymite, bismuthinite, tsumoite, aikinite and wittichenite (Yta et al., 2003; Canet et al., 2009). Thermobarometric constraints estimated bymeans of compositional chlorite and arsenopyrite geothermometers and the sphalerite geobarometer indicate temperatures that range from $243^{\circ}$ to $277^{\circ} \mathrm{C}$, from $300^{\circ}$ to $340{ }^{\circ} \mathrm{C}$, and an average pressure of $2.1 \mathrm{kbar}$ (Canet et al., 2009). Even though the above characteristics firmly advocate for a skarn model for the formation of late massive 
sulfide assemblages, a VMS model for the earliest cannot readily be ruled out yet. Such an overlapping of unrelated types of mineralization could have been possible as the ancient boundaries of the Guerrero composite terrane were extensively reactivated during the Late Cretaceous and the Cenozoic (see the history of fault reactivation in this region in NietoSamaniego et al., 2005, 2007). Ore deposits due to continental arc magmatism are abundant in the Zacatecas region, and both magmatic rocks and the associated ore deposits were emplaced opportunistically along terrane boundaries upon their reactivation. The nearest examples of Cenozoic continental arc-related ore deposits are the long-lived epithermal deposits in Zacatecas (Camprubí and Albinson, 2007), $20 \mathrm{~km}$ southeast of Francisco I. Madero.

\subsection{San Nicolás and El Salvador, Zacatecas}

At the San Nicolás and El Salvador deposits, VMS ores occur as stratiform lenses of polymetallic massive and semi-massive sulfide assemblages, and as sulfide stringers. All sulfide assemblages contain mostly sphalerite, chalcopyrite and pyrite; barite occurs in veinlets eventually forming stockworks underneath the polymetallic lenses. The stringer and stockwork associations are interpreted as feeder channelways for the upwelling hydrothermal fluids. The footwall contact of themain sulfide zone is typically uneven and gradational into a stringer zone, which commonly follow flow laminations in host rhyolites. Textures within the massive sulfides (e.g. curved laminations that mimic volcanic flow lamination and hyaloclastite breccias with jigsaw textures replaced by sulfides) suggest that they were partly formed by replacement of such rhyolites (Johnson et al., 2000). Sulfidebearing stringers occur either above, below, or laterally to the massive core of the lower sulfide zone of the stratiform lenses. The strongly zoned main sulfide lens is covered by basalts, volcanic tuffs and sedimentary rocks, and a synsedimentary fault that formed on one of the flanks of a rhyolite dome located below the orebodies was interpreted to be the main feeder channelway for such lens (Johnson et al., 2000). The upper part of the main orebody is rich in $\mathrm{Zn}$, $\mathrm{Au}$ and $\mathrm{Ag}$, while the lower is rich in $\mathrm{Cu}$. Gold and silver concentrations increase towards the upper part of the stratiform lenses. Chalcopyrite is consistently present in both stringers and massive lenses. Footwall rocks show propylitic 
alteration assemblages, which consist mainly in chlorite, calcite, and siderite-rich associations. Stringers of calcite, iron carbonates and barite stringers are common throughout the footwall of the deposit, and barite veinlets locally cut the sulfide masses. Almost all of the mafic rocks register clay or sericite alteration, from weak to intense including assemblages of clay or sericite, epidote and calcite, either replacing host-rock minerals or occurring as stringers.

\subsection{La Minita, Michoacán}

The mineralized lenses (N20 m thick) in the LaMinita cluster of deposits display a strong mineralogical zonation: (1) they are sulfide-rich at the bottom, with galena, sphalerite, and $\mathrm{Cu}$ sulfosalts; (2) below the bottom horizons some veinlets crop out which suggest the top of a scarcely visible stockwork, comprising barite, sphalerite and chalcopyrite (Fig. 5d); (3) the lenses are dominated by barite inmiddle portions, with some sphalerite, galena, chalcopyrite, tetrahedrite-tennantite, stromeyerite and proustitepyrargyrite (Fig. 5a,f,g), showing barite and sphalerite in the form of spherulites (Fig. 5e; barite is also found along with siderite replacing the host rudist reefs, see Fig. 5c), and (4) the lenses are dominated by Fe and Mn oxides at the top (Fig. 5a,b). At the La Blanca deposit, barite and pyrite veinlets were found underneath the barite lens, and were interpreted as feeder channelways, in the same manner as the sphalerite- and chalcopyritebearing veinlets at La Minita. Small amounts of chalcopyrite, bornite, and covellitewere also found close to the bottomof the La Codiciada deposit. Host rocks at La Minita were intensely chloritized and silicified, and jasper exhalites occur above the ore lenses. In the central part of themain lens there is a replacement assemblage of hematite,magnetite, pyrite, and sphalerite, and amagnetite replacive body also occurs 100m below the main lens. Similar replacement associations were found in the nearby La Blanca and the La Codiciada deposits.

The main ore lens at La Minita grades rapidly outwards to magnetite- and silica-rich rocks, which in turn give place to rudist reef limestones. These deposits formed at very shallow depths, as they are associated with coeval rudist reefs and show sedimentary 
structures that are characteristic of shallow submarine environments, thus suggesting a depth of formation of only a few m (below the sea level).

\subsection{Tizapa-Esmeralda-Santa Rosa, State of México}

The mantos and lenses at the Tizapa-Esmeralda-Santa Rosa cluster are conspicuously banded, and contain pyrite, sphalerite, galena, arsenopyrite, tetrahedrite-tennantite, freibergite, covellite, bornite, pyrrhotite, argentite, boulangerite, bournonite, meneghinite, zoubekite, stannite, sakharovaite, cassiterite, and electrum, plus some unidentified sulfosalts (Fig. 6d-f; Lewis and Rhys, 2000; Alfonso et al., 2011). Barite occurs in minor amounts. Pyrite- and chalcopyrite-rich stringers occur underneath the ore lenses, in associationwith iron carbonates and chlorite. Such zones were identified by Lewis and Rhys (2000) as feeder channelways. According to these authors, the massive sulfides may occur within a single stratigraphic horizon, were folded northwesterly (with thickened hinge zones) and inversely faulted, and thus their pieces were stacked. The stratigraphy of the Esmeralda deposit readily correlates with those at Tizapa and is dominated by felsic rocks (Lewis and Rhys, 2000). In this deposit, Rubinovich-Kogan (1988) identified cassiterite, pyrite, arsenopyrite, galena, sphalerite, boulangerite, freibergite, owyheeite, chalcopyrite, bournonite, semseyite, berthierite, and jamesonite. Unlike the rest of deposits in this cluster, in the Esmeralda deposit framboidal pyrite aggregates are well preserved and show tiny zoned overgrowths.

Due to metamorphic overprinting, hydrothermal alteration assemblages cannot easily be determined, but Lewis and Rhys (2000) ventured the occurrence of sericite-quartz alteration assemblages overprinted on footwall felsic rocks several $\mathrm{m}$ beneath the massive sulfide lenses. The alteration assemblages include layers of coarsegrained quartz, pyrite and chalcopyrite. Also, chlorite-pyrite assemblages occur at $\sim 45 \mathrm{~m}$ beneath the sericite-quartz zone, developed on andesitic metavolcanic rocks. Non-pervasive alteration occurs beneath chlorite-rich associations, and includes stringers of pyrite, quartz, calcite and sphalerite.

The rocks that host the VMS mineralization in the Tizapa- Esmeralda-Santa Rosa group of deposits are mainly schists made up of quartz, chlorite, muscovite and calcite (Fig. 6a-c). Quartz crystals form local rounded aggregates with internal serrated sutures and 
occasionally have undulated extinctionwith development of sub-grains due to deformation; quartz aggregates are often wrapped bymuscovite lattices describing ribbon texture and adjacent fine-grained quartz pressure shadows (Fig. 6a). Chlorite and muscovite are abundant in these schists and usually show lepidoblastic textures; muscovite aggregates display local decussated textures (Fig. 6c). Calcite is pervasive and forms syndeformational sparry poikiloblasts, and micro-sparry fibrous layers parallel to the general schistosity or as fracture lining. Rarely, sillimanite (fibrolite variety) and postdeformational pinnitized cordierite poikiloblasts occur. Schistosity is sometimes crenulated (Fig. 6b) and shows at least two deformational stages. The presence of granoblastic and decussate textures, sillimanite and post-deformational cordierite poikiloblasts is indicative of contact metamorphism events. Lewis and Rhys (2000) determined four main periods of post-mineral deformation: D1, with development of penetrative foliation, which is preserved only locally due to overprinting by later deformation events; D2 presents westvergent folding, thrusting, and penetrative strain, which formed the dominant structures controlling the distribution of stratigraphic units and ore lenses, and is considered as themain deformation stage; D3 shows foldingwith a regionalwest-trending anticline, accompanied by formation of west-trending crenulation (Fig. 6a,b); and D4, brittle deformation and faulting. Sulfideminerals, mainly pyrite, control the development of the general schistosity of the rock. Euhedral to subhedral pyrite crystals are partially welded showing local annealing textures with contacts at $120^{\circ}$; pyrite grains fragmented and affected by fragile deformation are largely restricted to those ore samples with little or nonexistent matrix (lacking sulfide "soft"matrix). Variable proportions of sphalerite, chalcopyrite and galena between pyrite grains (Fig. 6d-f) show a variety of textures indicative of plastic deformation and recovery/recrystallization at lower temperature than pyrite (e.g., Pesquera and Velasco, 1993; Barrie et al., 2010).

\subsection{Tlanilpa-Azuláquez, Guerrero}

The fine-grained, thin, and broad (stretching $\sim 100 \mathrm{~m} 2$ ) mantos in the TlanilpaAzuláquez cluster are parallel to stratification (and foliation), and contain pyrite, galena, sphalerite, chalcopyrite, tetrahedrite-tennantite, bornite, covellite, barite, and various 
unidentified sulfosalts (Rhys et al., 2000, and our own observations). There is evidence for synsedimentary reworking of ores. Banded barite occurs with sulfides in many localities, and black chert layers occur in close association with massive sulfide lenses; both associations were interpreted as the result of distalmineralization processes (Rhys et al., 2000), either in lateral positions or towards the top of the ore lenses. Also, quartz-sulfide breccia veins occur, enveloped by alteration zones of K-feldspar-sericite-carbonate, and quartz veinlets, stringers and stockworks occur in several localities (Rhys et al., 2000). Such structures may be at least $1.4 \mathrm{~km}$ long, are younger than the massive sulfide lenses, and show a strong vertical mineralogical zoning, from coarse-grained pyrite-quartzsphalerite-galena associations at deeper levels, to drusy gold-bearing arsenopyritechalcopyrite-quartz associations on ridge tops (Rhys et al., 2000). It is uncertain whether these breccia veins are associated with the VMS lenses or represent a much later (Cenozoic?) mineralizing event.

\subsection{Rey de Plata, Guerrero}

The $\mathrm{Zn}-\mathrm{Pb}-\mathrm{Cu}-\mathrm{Ag}-\mathrm{Au}$ Rey de Plata deposit consists of both stockworks and lenses or mantos developed in schists and metavolcanics of felsic composition; ore in Rey de Plata is composed of pyrite, sphalerite, galena, bornite, chalcopyrite, pyrargyrite, tetrahedritetennantite, native gold, arsenopyrite and jamesonite, along with gypsum, barite and calcite as gangue phases (Miranda-Gasca et al., 2001). The lens-shaped bodies range in size from 3 to $60 \mathrm{~m}$ thick, from 300 to $1200 \mathrm{~m}$ long, and from 100 to $500 \mathrm{~m}$ wide (Monter-Ramírez and Zavala-Esquivel, 2011). The Tehuixtla orebody shows strong zoning: the bottomconsistsmainly of pyrite (including framboidal aggregates), chalcopyrite and bornite (Kuroko-type "yellow ore"), and the top consists mainly of pyrite, sphalerite, galena, barite and, sporadically, silver sulfosalts (Kuroko-type "black ore") (Monter-Ramírez and ZavalaEsquivel, 2011). Sulfide assemblages are mostly banded, and show weak tectonic foliation. Gold occurs in the upper part of the deposit, and is associated with ankerite-rich silicification. The Cuerpo Superior (Upper Orebody) contains disseminated, semi-massive and massive associations of pyrite, chalcopyrite, bornite, covellite and chalcocite at the bottom, and sphalerite, galena and sporadic silver sulfosalts at the top. In the central part of this orebody are found barite veinlets and a chalcopyrite, pyrite and gold-bearing 
stockwork, which may represent feeder channelways (Monter-Ramírez and ZavalaEsquivel, 2011). The Cuerpo Intermedio and Cuerpo Inferior (Intermediate and Lower Orebodies; see Figure 4 in Monter-Ramírez and Zavala-Esquivel, 2011) display similar

mineralogy, zoning and structure; however, galena-rich associations in Kuroko-type "black ores" of the latter orebody generally display extremely high silver contents (over $1000 \mathrm{~g} / \mathrm{t}$ $\mathrm{Ag}$ ). Both the ores and host rocks show plastic deformation, developed mylonites locally, and underwent metamorphism in the greenschist facies.

\subsection{Campo Morado-Suriana, Guerrero}

At least eight important mineralized lenses and mantos are known in the CampoMorado-Suriana cluster (Oliver et al., 2000, 2001), namely the Reforma, El Rey, Naranjo, El Largo, Estrella de Oro, San Rafael, El Profundo, and G9 orebodies (Fig. 3). They consist of pyrite (locally showing framboidal habits and zoned overgrowths), quartz, ankerite, sphalerite, galena, chalcopyrite, tetrahedrite-tennantite, freibergite, arsenopyrite, pyrrhotite, and electrum. The deposits show a zoned stratigraphy with (1) $\mathrm{Cu}$-rich zones towards the bottom, (2) a central pyrite-rich zone, which grades upwards to (3) a pyritesphalerite zone, and then (4) to an upper sphalerite-galena rich zone that contains the highest grades in precious metals (Oliver et al., 2000, 2001). The content in silver sulfosalts increases upwards in the lenses. Gold occurs as free electrumand encapsulated in pyrite. Silicification is common underneath the ore lenses, associated to stockworks, veinlets and patches of quartz and ferroan dolomite-ankerite, with local selvages of chlorite and patches of disseminated pyrite, chalcopyrite and sphalerite. Sericite is abundant in hangingwall rocks directly above massive sulfide lenses, andmay occur in heterolithic volcanic rocks that are intensely chloritized beneath the lenses, whereas kaolinite-quartz assemblages are abundant in both proximal and distal hangingwall rocks (Oliver et al., 2000, 2001). The main lens (Reforma body) was overturned by deformation (Fig. 3), as suggested by the differential distribution of the highest $\mathrm{Pb}, \mathrm{Zn}, \mathrm{Ba}, \mathrm{Ag}$, and $\mathrm{Au}$ contents (at the present bottom), and those of $\mathrm{Cu}$ and $\mathrm{SiO} 2$ (at the present top). The original upper part of the deposit is characterized by a sequence of cherts interestratified with black shales, thus suggesting their formation as exhalites. 


\subsection{The deposits in the Guanajuato ranges}

The VMS deposits in the León-Guanajuato trend are hosted by the volcano-sedimentary Esperanza Formation. The ore deposits at San Ignacio (Los Mexicanos) are massive lenses made up of pyrite, chalcopyrite, sphalerite, bornite, and pyrrhotite, with late stockwork-like veinlet sets of quartz and chalcopyrite surrounded by strong silicification (Mengelle-López et al., 2006, 2013). The uppermost portion of the lenses is significantly weathered. Similar features can be observed at the Yolanda deposit (El Guapillo), where the orebodies display extensive supergene oxidation, represented by a conspicuous development of $\mathrm{Cu}$ and $\mathrm{Zn}$ sulfate crusts.

The ores at El Gordo and Los Gavilanes formbothmassive lenses and disseminated bodies. Such lenses contain pyrite, pyrrhotite, chalcocite, digenite, bornite, galena and magnetite at El Gordo, and pyrite, marcasite, pyrrhotite, sphalerite, and galena at Los Gavilanes (Hall and Gómez-Torres, 2000b,c). Gold contents are high in the northeastern part of the Los Gavilanes deposit. Sulfides are generally coarse-grained and textural evidence suggests that replacement occurred extensively. Sedimentary banding within massive sulfides is relatively rare, and pyrite displays framboidal textures locally. Silicified limestones at Los Gavilanes developed actinolite-tremolite, wollastonite and garnet contact metamorphism assemblages due to the emplacement of Cenozoic dykes (Hall and GómezTorres, 2000c).

Additional massive and semi-massive sulfide occurrences in this region are Cerro Colorado, Tres Estrellas, Peña Rica, and Paz de México, all of them also hosted by felsic and andesitic rocks belonging to the Esperanza Formation. Such occurrences include siliceous exhalites, calc-silicate assemblages and, locally, gossan assemblages (Hall and Gómez-Torres, 2000c).

\subsection{Other VMS deposits}

The mantos at Arroyo Seco (Michoacán) are constituted by tetrahedrite-tennantite, galena, pyrargyrite, sphalerite, argentite, chalcopyrite and pyrite, with barite, calcite, and 
quartz. The deposits at Ixcuinatoyac (Guerrero) contain chalcopyrite, pyrrhotite, pyrite, magnetite, hematite, and sphalerite at the La Dicha deposit, and barite and hematite at the Esperanza deposit (Klesse, 1968). The Cyprus-type Copper King deposit (Guerrero) comprises several lenses overlain by basaltic flows. Underneath the main lens occurs a stockwork composed by chalcopyrite, pyrite, quartz and chlorite. Chalcopyrite and pyrrhotite are abundant in the lower part of the lenses, whereas sphalerite is abundant towards the top, along with high $\mathrm{Pb}$ and $\mathrm{Ba}$ grades, which are associated with a silicification zone. A silicarich horizon occurs laterally to the main lens, and is interpreted as an exhalite. Host rocks underwent metamorphism in the greenschist facies; pyritewas recrystallized, and chalcopyrite and pyrrhotite experienced plastic deformation.

\section{Fluid inclusion studies}

Fluid inclusion studies in Mexican VMS deposits are scarce: most of them are preliminary or semi-systematic studies so far and, instead of mainstream journals or publications, they have to be found in rather hard-to-find sources (i.e. unpublished reports and thesis). Macías and Solís (1985) reported homogenization temperatures of aqueous inclusions between $220^{\circ}$ and $265^{\circ} \mathrm{C}$, and salinities around $5 \mathrm{wt} \% \mathrm{NaCl}$ equiv. fromthe Cuale deposits, Jalisco. Mengelle-López (2009) reported temperatures of homogenization of aqueous inclusions that range from $111^{\circ}$ to $321^{\circ} \mathrm{C}$, and salinities that range from 11.5 to 18.1 wt.\% $\mathrm{NaCl}$ equiv., with detectable contents of $\mathrm{CO} 2, \mathrm{CH} 4$ and N2 (through Raman microspectroscopy), from the San Ignacio mine, Guanajuato. Miranda-Gasca (1995) and Miranda-Gasca et al. (2001) reported temperatures of homogenization of aqueous inclusions that range from $140^{\circ}$ to $380{ }^{\circ} \mathrm{C}$, and salinities that range from 1.9 to 9.2 wt.\% $\mathrm{NaCl}$ equiv., from the Rey de Plata deposit, Guerrero. Zamora-Vega (2004) and Torró et al. (2011) reported temperatures of homogenization of aqueous inclusions that range from $190^{\circ}$ to $420{ }^{\circ} \mathrm{C}$ and salinities up to $22 \mathrm{wt} . \% \mathrm{NaCl}$ equiv., along with $\mathrm{CO} 2$-rich inclusions with detectable contents of $\mathrm{CH} 4$ and N2 (through Raman microspectroscopy), from the Tizapa-Santa Rosa deposits, State of México. However, González-Partida (1984) reported a rather intriguing fluid inclusion assemblage in deep quartz veins at Tizapa, in which temperatures of homogenization range from $440^{\circ}$ to $550{ }^{\circ} \mathrm{C}$, and salinities range from 39.7 
to 64.7 wt.\% $\mathrm{NaCl}$, and from 35.9 to $43.5 \mathrm{wt} \% \mathrm{KCl}$ (salinities were calculated in this paper).

In this paper, we include new extensive microthermometric studies of fluid inclusions, whichwere carried out in the Cuale, El Rubí (Talpa de Allende district), La Minita-Sapo Negro and Campo Morado-Suriana deposits. The studied samples were doubly polished sections (100 to $150 \mu \mathrm{m}$ thick). Primary, pseudosecondary and secondary inclusions were found. The analyzed inclusions are liquid-rich (their degree of filling varies from 0.60 to 0.90 ) and therefore they homogenized systematically into a liquid phase, contain no daughter crystals, and their diameters range from 5 to $25 \mu \mathrm{m}$. Primary fluid inclusions occur in growth zones parallel to crystal faces, or occur as solitary inclusions or solitary groups of inclusions lacking healed fractures (where growth zones could not be identified). Pseudosecondary inclusions occur along planes crosscut by later growth zones. Many primary and pseudosecondary inclusions showed evidence of necking and some leakage. Necking is manifested in groups of fluid inclusions that showawide range of vapor to liquid ratios. For this paper, only primary and pseudosecondary inclusions were analyzed. Microthermometric studies were carried out on a Linkam THMSG600 heatingfreezing stage. Calibration runs show that the measurements are accurate to $\pm 0.2{ }^{\circ} \mathrm{C}$ for low-temperature measurements, and to $\pm 2{ }^{\circ} \mathrm{C}$ for high-temperaturemeasurements. Salinitieswere calculated by using freezing point depression temperatures in the SALTY software by Bodnar et al. (1989) and Bodnar (1993). Salinities for fluid inclusions with daughter halite and sylvite crystals in the Tizapa deposit were calculated in this paper for the available microthermometric data from González-Partida (1984), and calculations were done by using solubilization temperatures through the state equations by Sterner et al. (1988).

The results of microthermometric studies are summarized in Table 1 and in Fig. 7. The analyzed barite, sphalerite and quartz samples were taken from stockwork zones, nonrecrystallized sphalerite in massive ores as well as pyrrhotite-coated sphalerite spherulites, and nonrecrystallized barite mantos. Eutectic temperatures for all inclusions in the studied VMS deposits are below $-40{ }^{\circ} \mathrm{C}$ and point to the existence of complex polysaline solutions (e.g., Crawford, 1981; Davis et al., 1990). Hydrohalite melting temperatures are $-21.1 \pm$ 
$0.5{ }^{\circ} \mathrm{C}$, which imply $\mathrm{NaCl}$-dominated brines. The ranges for temperature and salinity data for the analyzed deposits are as follows.

At the Cuale deposits:

- inclusions in quartz from stockwork zones yielded temperatures of homogenization that range from $270^{\circ}$ to $400{ }^{\circ} \mathrm{C}$ and salinities from 10 to $14 \mathrm{wt} . \% \mathrm{NaCl}$ equiv.;

- inclusions in sphalerite from massive bodies yielded temperatures of homogenization that range from $200^{\circ}$ to $260{ }^{\circ} \mathrm{C}$ and salinities from 3 to $13 \mathrm{wt} . \% \mathrm{NaCl}$ equiv.;

- inclusions in sphalerite from "sphalerite-spheres" yielded temperatures of homogenization that range from $205^{\circ}$ to $260{ }^{\circ} \mathrm{C}$ and salinities from 3 to 7.5 wt. $\% \mathrm{NaCl}$ equiv.

At the El Rubí deposits:

- inclusions in quartz from stockwork zones yielded temperatures of homogenization that range from $160^{\circ}$ to $405^{\circ} \mathrm{C}$ and salinities from 3 to $14.2 \mathrm{wt} \% \mathrm{NaCl}$ equiv.;

- inclusions in sphalerite from massive bodies yielded temperatures of homogenization that range from $205^{\circ}$ to $255^{\circ} \mathrm{C}$ and salinities from 3.5 to $13.7 \mathrm{wt} \% \mathrm{NaCl}$ equiv.

At the La Minita-Sapo Negro deposits:

- inclusions in sphalerite from stockwork zones yielded temperatures of homogenization that range from $140^{\circ}$ to $360{ }^{\circ} \mathrm{C}$ and salinities from 5 to 16 wt. $\% \mathrm{NaCl}$ equiv.,

- inclusions in sphalerite and quartz from massive bodies yielded temperatures of homogenization that range from $155^{\circ}$ to $305{ }^{\circ} \mathrm{C}$ and salinities from 3.5 to 11 wt.\% $\mathrm{NaCl}$ equiv.

- inclusions in barite from massive bodies yielded temperatures of homogenization that range from $110^{\circ}$ to $200{ }^{\circ} \mathrm{C}$ and salinities from 3.2 to $16 \mathrm{wt} \% \mathrm{NaCl}$ equiv.

At the Campo Morado-Suriana deposits, inclusions in quartz from stockwork zones yielded temperatures of homogenization that range from $110^{\circ}$ to $320^{\circ} \mathrm{C}$ and salinities from 3.3 to 8 wt. $\% \mathrm{NaCl}$ equiv. 


\section{Sulfur isotope studies}

As for fluid inclusions, published sulfur isotope data in Mexican VMS deposits are scarce. However, González-Partida (1984) and Torró et al. (2011) reported several $\delta^{34} S$ data from the Tizapa-Santa Rosa cluster of deposits, which range from -6.5 to $2.5 \%$ (Fig. 8). Also, Mengelle-López (2009) reported $\delta^{34} S$ data for the San Ignacio mine that range from -3.4 to $5.9 \%$.

Sulfur isotope compositions were analyzed in pure separates of pyrite, sphalerite, galena, chalcopyrite, pyrrhotite, barite and gypsum from all stages of mineralization in the Campo Morado-Suriana, Cuale, El Rubí (Talpa de Allende district), Tizapa-Santa Rosa, La Minita-Sapo Negro and Copper King deposits. The sulfide and sulfate separates from Mexican VMS deposits were obtained by handpicking under the microscope from samples previously studied in polished section. The sulfides were combusted with $\mathrm{CuO}$ at $1000{ }^{\circ} \mathrm{C}$ to release $\mathrm{SO}_{2}$. The $\mathrm{SO}_{2}$ was analyzed using a Finnigan continuous flow spectrometer available at the Universitat de Barcelona (Spain). Precision of the analyses is better than $\pm 0.2 \%$. Sulfur isotope composition is expressed as the delta per mil (\%o) values relative to the Canyon Diablo Troilite (CDT) standard.

The obtained isotopic data are displayed in Table 2 and in Fig. 8. The obtained $\delta^{34} \mathrm{~S}$ data range

- from 1 to $7 \%$ for sulfides at the Cuale deposits;

- from -3 to $-1.5 \%$ and from 2 to $6 \%$ ofor sulfides, and $22.6 \%$ for late sulfates at the El Rubí deposits;

- from -13 to $-17 \%$ and from 0 to $-2 \%$ for sulfides, and 16 to $17.5 \%$ for sulfates at the La Minita-Sapo Negro deposits;

- from -53 to $-59 \%$ and from -3 to $-6 \%$ for sulfides at the Campo Morado-Suriana deposits;

- from -15.2 to $2.8 \%$ for sulfides at the Tizapa-Santa Rosa deposits (data from González-Partida, 1984; Torró et al., 2011, plus new data), although such data displays two main peaks from -3 to $-2 \%$ and from -1 to $0 \%$;

- from -6.5 to $4.8 \%$ for sulfides at the Copper King Cyprus-type deposits. 
It is worth mentioning that the lowest $\delta^{34} \mathrm{~S}$ values obtained in the CampoMoradoSuriana deposits correspond to sulfide samples collected in the deepest portions of massive sulfide lenses, and $\delta^{34} \mathrm{~S}$ values of sulfides in early stages of mineralization in the Cuale and El Rubí deposits range -3 to $-1.5 \%$.

\section{Discussion}

\subsection{Further exploration (northwards)}

The exploration endeavor for VMS deposits in Mexico has been traditionally focused on the edges and within the Guerrero composite terrane, where most of such deposits actually occur (Fig. 1), besides the trail of Mesozoic VMS deposits follows northwards into other terranes. Such is the case of (1) the Valle de Los Olivos deposit in the Parral terrane, near the border with the Cortés terrane (Clark and Fitch, 2009) in southern Chihuahua, (2) the Cedros Island deposits in the Vizcaíno terrane, and (3) the Calmallí and La Prosperidad deposits in the Alisitos arc terrane, in the Baja California Peninsula. However, the Valle de Los Olivos deposit in the Parral terrane stands as an uncanny case in Mexico, as it seems to be the only Mesozoic VMS deposit (unless its age estimation has been grossly mistaken) that is hosted by a terrane with a Paleozoic basement, and therefore this suggests that marginal Mesozoic sequenceswithin similar terranes are prospective for VMS deposits. The Alisitos arc terrane, unlike the Tahue terrane, is a favorable area for exploration for VMS and other types of deposits (Figure 5 in Camprubí, 2013), as generalized extension took place in this area during the Mesozoic, similarly to the southern terranes of the Guerrero composite terrane. In this sense, Busby et al. (2006) identified two tectonic evolutionary phases in theAlisitos terrane during the Lower Cretaceous: a first phase defined by an extensional oceanic arc, and a second phase defined by a rifted oceanic arc, whereas the accretion of the Alisitos arc terrane to thewestern edge ofMexico occurred by underthrusting along high-angle reverse faults at about $105 \mathrm{Ma}$.

The metallogeny in the northern part of the Guerrero composite terrane, which encompasses the Tahue terrane and the northern portion of the Zihuatanejo terrane (see Fig. 1), is vastly unknown. The Mesozoic stratigraphy of this region is poorly known, as it is 
covered by a thick pile of the Cenozoic volcanism or intruded by the Sinaloan batholiths, which are hindering any surveys on Mesozoic assemblages. Therefore, the potential for VMS or other types of deposits in this region cannot be readily inferred. In addition, itmay be suggested that the distribution of VMS deposits in Fig. 1 (mostly along the borders of the Guerrero composite terrane, and only a few deposits inland within it) may be partly due to the obscuring effect of the thick Cenozoic volcanic pile, as these deposits (if any) would remain unnoticed underneath it. Therefore, the distribution of VMS deposits could be regarded as an artifact, as no geological evidence whatsoever forbids the occurrence of such deposits inland. The potential for Kuroko-type VMS deposits in the Tahue terrane is unknown, but it seems unlikely that there is any, as the available regional evidence does not support broad and long-lived extension as it does in the southern part of the Guerrero composite terrane. That, despite the fact that the volcano-sedimentary sequences in the Tahue terrane and those in the southern terranes have similar characteristics. The contrasting occurrence of types/styles of ore deposits between the northern and southern halves of the Guerrero composite terrane (apparently, with only deposits associated with ultramafic-mafic complexes in the northern half) suggests a different geological history and potential for ore deposits that needs further attention.

New perspectives arise in the exploration of VMS deposits, as at least some deposits in the Guanajuato ranges (namely, San Ignacio) happen to remarkably occur in the continental margin of Oaxaquia (Sierra Madre terrane) instead of the Guerrero composite terrane. In this area, VMS deposits are hosted in 151-145 Ma rhyodacitic volcanic rocks embeddedwithin Tithonian continent-recycled quartz-arenites and shales of the Esperanza Formation, which derived from the erosion of sources located in the continental interior (Martini et al., 2011). The continental provenance of the Esperanza Formation suggests that these rocks were deposited on the continental side of the Arperos back-arc basin (the Sierra Madre side), quite far from the detrital influx of the Guerrero composite terrane. The felsic volcanic rock assemblages that host VMS deposits in this area may therefore be interpreted as due to crustal melts related to the continental back-arc extension. Such statement is supported by (1) the peraluminous character of these rocks, (2) the ubiquitous presence of Paleozoic to Proterozoic inherited zircons, (3) the presence of quartz xenocrysts, and (4) the presence of xenoliths of sedimentary and metamorphic rocks, which underline the 
significant contribution of continental or continent-recycled sediments in the genesis of these magmas (Martini et al., 2011). Following this scenario, the volcanic rock assemblages that host VMS deposits may conform a felsic magmatic province that developed within the Arperos basin during the continental stage of back-arc extension. Then, it seems reasonable that such felsic volcanic rocks are not to be exclusively found on thewestern side (the Guerrero composite terrane side) of the Arperos Basin, but they may also have been emplaced on its continental (eastern) side. Therefore, contrary to previous ideas, this suggests the possibility that the continental margin of Oaxaquia can be prospective for VMS deposits.

\subsection{Further exploration (southwards)}

It is a common knowledge that evolved back-arc basins and intraoceanic arcs are keen environments for the formation of VMS deposits (see the contributions in one of the keystone collection of papers for such 'awareness', at Economic Geology v. 88 n. 8; e.g., Bendel et al., 1993; Binns and Scott, 1993; Fouquet et al., 1993; Herzig et al., 1993; Precejus and Märten, 1993; also, Franklin et al., 2005). However, the Jurassic-Cretaceous volcanic belt in Mexico (a.k.a. the Mesozoic Pacific margin) is somewhat ill defined, in the sense that no persuasive enough reconstructions are hitherto found in the current literature that outline the precise time span and space position of the different arc segments and their associated back-arc basins. Also, no clear ideas (or 'unified theories') are given about the 'extent of the extension' for the latter. The Mexican VMS deposits were initially compared by Charoy and González-Partida (1984) with Kuroko-type deposits, as the Cenozoic green tuff belt in Japan is associated with a volcanic arc that led to the formation of a back-arc basin during the Miocene, which hosts most of the VMS deposits in Japan (Ohmoto and Skinner, 1983). Also, the Cretaceous back-arc basin of the Andes (Lapierre et al., 2000; Pindell and Kennan, 2001) shows a metallic fertility akin to the Mesozoic VMS deposits in Mexico. Miranda-Gasca (1995, 2000, 2003), Bissig et al. (2008), Mortensen et al. (2008), Camprubí (2009), and Clark and Fitch (2009) confirmed the affinity of the Mexican deposits with the Kuroko type, provided that their distribution outlines, at different extents, the evolved Jurassic to Cretaceous back-arc basins in the region (e.g., the Arperos basin). In 
this paper we consider that such affinity remains unchallenged despite the lingering substantial gaps in the knowledge about the Jurassic to Cretaceous geodynamic evolution of the Pacific margin in Mexico.

Other deposits in southern Mexico, namely the Copper King and Ixcuinatoyac deposits, are found in the Guerrero composite terrane but, in their own ways, they constitute singularities in the Mexican VMS landscape. On the one hand, the Copper King Cyprustype deposits are associated with the Las Ollas-Camalotito-Loma Baya-El Tamarindo coastal trail of ultramafic-mafic complexes. On the other hand, the deposits at Ixcuinatoyac were likely formed during the Triassic, unlike the vast majority of VMS deposits in the Guerrero composite terrane, which formed between the Late Jurassic and the Early Cretaceous (Figure 13 in Camprubí, 2013). Besides Ixcuinatoyac, only the deposits in the ultramafic-mafic complex in the Vizcaíno Peninsula are known to be Triassic in age. Therefore, the metallogeny during that period remains vastly ill defined in Mexico.

Several authors have long stood for the idea that the Jurassic to Cretaceous magmatic belt in Mexico formed, at least partly, on continental crust (González-Partida and TorresRodríguez, 1988; Tardy et al., 1994; Goldhammer and Johnson, 2001; among others). Similarly, Busby-Spera (1988) opted for an "Andean-type arc" during the Early Mesozoic in Arizona, California and western Nevada. In such context, two questions may be put forth: why such a volcanic belt is not found between Oaxaca and the Chiapas range? and where VMS should be looked for south of the Guerrero composite terrane, if any? In the model established by Pindell and Kennan (2001) the formation of a proto-Gulf of Mexico is considered, which would have started during the Upper Jurassic and culminated during the Cretaceous as an evolved rift zone with MORB volcanism. The latter was identified by Lapierre et al. (2000) in central Mexico as due to oceanic spreading. In the model by Pindell and Kennan (2001), such rift did not extend towards the Gulf of Mexico megabasin, and the resulting basin ended up in the region where presently the Los Tuxtlas volcanic massif is found, in southern Veracruz. Following the tectonic reconstruction of these authors, such basin would be located east of the Chortis Block but, according to Carfantan (1981), the volcanic arc and its marginal basin were developed west of the "Oaxaca High" (and/or the Chortis Block). The present position of such Jurassic to Cretaceous arc and marginal basin is found in Central America (namely, the El Tambor Formation in 
Guatemala, Honduras and Nicaragua), in the Chortis Block. Relict portions of this Jurassic to Cretaceous volcanic belt in the Chiapas Range are found in the "Chontal Arc" (Carfantan 1981, 1983), which consists of trachyandesites, volcano-sedimentary breccias, graywackes, and interstratified volcanic tuffs, schists and platform limestones, in a similar fashion as it occurs in the Teloloapan-Taxco region in the state of Guerrero where the Rey de Plata VMS deposit is found. If we concurred with the hypothesis by Pindell and Kennan (2001), exploration for VMS deposits should be focused on the states of Veracruz and Puebla (where none are found for the Jurassic-Cretaceous period so far), whereas if we do sowith the hypothesis by Carfantan (1981) such deposits should be found in Central America (i.e., the Oxec Cyprus-type deposit in Guatemala; Petersen, 2000), and there would be no chance to find them in Oaxaca and Chiapas. Given the available evidence, in this paper we consider the latter as the most plausible explanation.

\subsection{Fluid inclusion and sulfur isotope data}

Microthermometric data of fluid inclusions from selected Mesozoic VMS deposits (Cuale, La Minita, El Rubí, and Campo Morado), plus data from the Rey de Plata and San Ignacio deposits (taken from Miranda-Gasca, 1995; Mengelle-López, 2009, respectively) span ranges of calculated salinities between 2.5 and 20.0 wt.\% $\mathrm{NaCl}$ equiv., and temperatures of homogenization between $110^{\circ}$ and $420{ }^{\circ} \mathrm{C}$ (Table 1 and Fig. 7). The temperature vs. salinity field obtained in this study is quite wider than the one considered as typical for Kuroko deposits and for modern fluids from seafloor vents (as of Wilkinson, 2001; Hannington et al., 2005). Such fluids, despite the various clusters of temperature and salinity that each deposit displays, encompass the four thermocompositional categories of mineralizing fluids for VMS deposits outlined by Sato (1972). Most fluid inclusions from the analyzed deposits are less dense and hotter than 'evolved', deeply circulated seawater (i.e. modified through water-rock interaction with the underlying volcano-sedimentary rocks), although some data hit the field of type-I fluids (low temperature hydrothermal fluids denser thanmodified seawater; Fig. 7). Broadly speaking, this suggests the entrainment of fresh seawater, modified seawater, and magmatic fluids (Franklin, 1996; Hannington et al., 2005). It seems futile to invoke the entrainment of the different types of 
magmatic fluids or of seawater modified at variable degrees without any further fluid geochemical data for the studied VMS deposits. However, in the case of the Tizapa deposits, González-artida (1984) reported $\delta^{18} \mathrm{O}$ and $\delta 2 \mathrm{H}$ data for water in equilibrium with analyzed chlorite that plot between themagmatic water compositional box and modern seawater (SMOW; see Figure 4 in González Partida, 1984) or within the compositional box for andesitic water (Giggenbach, 1992a,b) or felsic magmatic water (Taylor, 1992), thus emphasizing the involvement of both seawater and magmatic fluids.

It is worth noting, though, that a small set of fluid inclusions from stockwork quartz in the Tizapa deposit (see top diagram in Fig. 7; González-Partida, 1984) yielded salinity and temperature values far off the chart pictured above: temperatures of homogenization range from $440^{\circ}$ to $550{ }^{\circ} \mathrm{C}$, temperatures of solubilization of daughter halite crystals range from $401^{\circ}$ to $536{ }^{\circ} \mathrm{C}$, and temperatures of solubilization of daughter sylvite crystals range from $100^{\circ}$ to $180{ }^{\circ} \mathrm{C}$. Using the state equations of Sterner et al. (1988), such solubilization temperatures correspond to $39.7-64.7$ wt.\% $\mathrm{NaCl}$ and $35.9-43.7$ wt.\% $\mathrm{KCl}$, respectively (Table 1 and topmost diagram in Fig. 7). Such extremely high temperature and salinity fluids are rather uncommon in either fluid inclusion assemblages in fossil VMS deposits or in seafloor moden vent deposits (e.g., Franklin et al., 2005; Hannington et al., 2005). They are indeed uncommon but not unlikely: similar brines have been found to occur in modern and fossil hydrothermal vents associated to relatively shallow plutonic rocks in different tectonomagmatic oceanic settings. Examples for it are the Oceanographer Transform along the Mid-Atlantic Ridge, the Mathematician, southwest Indian and Costa Rica Ridges, and the Troodos, Semail and Trinity ophiolitic complexes, among other locations (e.g., Stakes and Vanko, 1986; Kelley and Delaney, 1987; Kelley and Robinson, 1990; Nehlig, 1991; Vanko and Stakes, 1991; Kelley et al., 1992; Vanko et al., 1992; Hayes, 1996; Vanko and Laverne, 1998). Among the existing models for the occurrence of such hightemperature and high-salinity brines, it stands out the possibility that (1) these were formed by phase separation of deeply entrained evolved seawater and/or magmatic brines (brines resulting from boiled-off vapor migration), or (2) they exsolved directly from latestage highly differentiated melts with no significant role for phase separation (e.g., Kelley et al., 1992; de Ronde, 1995). Either way, it is rather likely that such brines represent inputs of magmatic brines from shallow intrusions (with or without a significant entrainment of 
deeply circulated seawater), and we venture that such might be the case for the microthermometric data obtained in the TizapaVMS deposit by González-Partida (1984). For further reading on this matter, see the discussions in Moss et al. (2001) and Ioannou et al. (2007) for both active seafloor hydrothermal systems and 'fossil' VMS deposits. Similar to most Kuroko-type deposits, the studied VMS deposits in this paper display a characteristic thermal zonation that has a correspondence with the type of ore assemblages, and therefore they parallel the typical evolution of such type of deposits. For instance, at the Cuale and El Rubí deposits (1) yellow ores and stockworks (Cu-rich ores) are associated with the highest temperatures $\left(270^{\circ}\right.$ to $\left.\sim 400{ }^{\circ} \mathrm{C}\right)$, (2) black ores $(\mathrm{Zn}-\mathrm{Pb}$ associations) are associated with "intermediate" temperatures $\left(200^{\circ}\right.$ to $\left.\sim 260{ }^{\circ} \mathrm{C}\right)$, and (3) peripheral $\mathrm{Zn}-\mathrm{Pb}$ ores rich in $\mathrm{Ag}$ and $\mathrm{Au}$ (commonly distal, about $\sim 200 \mathrm{~m}$ away from feeder channelways) are associated with the lowest temperatures $\left(170^{\circ}\right.$ to $\left.\sim 200{ }^{\circ} \mathrm{C}\right)$. Such characteristic thermal zonation correlateswith (1) a decrease in salinity of ore-forming fluids, from 14 to $\sim 3 \mathrm{wt} . \% \mathrm{NaCl}$ equiv., (2) an increasing content of barite upwards in the stratiformdeposits and with time, and (3) themarginal occurrence of Fe andMn oxide assemblages (outwards, both horizontally and vertically). Such thermal, salinity and mineralogical zonation pattern (thus reflecting oxidation) is explained as an increasing entrainment of seawater leading to ore deposition from the central to the peripheral paleohydrothermal systems and during their waning stages. A similar evolution is characteristic to many VMS deposits and their actualistic counterparts in present seafloor vents (Wilkinson, 2001; Franklin et al., 2005; Hannington et al., 2005), and constitutes a feature shared with sedimentary-exhalative (SEDEX) deposits, like the Proterozoic Selwyntype $\mathrm{Pb}-\mathrm{Zn}$ deposits in Australia (Cooke et al., 2000).

As another general feature (e.g., Wilkinson, 2001), in the deposits where fluid inclusions from both stockwork and (either earlier or later) stratiform assemblages were studied (Cuale, La Minita, and El Rubí) inclusion fluids in the stockwork display higher temperatures of homogenization and generally higher salinity than the stratiform orebodies (Fig. 7). Also, in the above cases, where the different mineral assemblages were clearly determined and associated to the early, middle and late stages of mineralization (early stages in stockwork and middle stages in stratiform orebodies for the La Minita and El Rubí deposits, and early stage in stratiform deposits and middle stage in stockwork 
mineralization for the Cuale deposits), the behavior of temperatures and salinities with time is about the same as recorded in the VMS deposits of the archetypical Hokuroku district in Japan (Pisutha-Arnond and Ohmoto, 1983): (1) relatively low temperatures and salinities in early and late stages ofmineralization, and (2) relatively high temperatures and salinities in middle stages (diagram at the bottom in Fig. 7). As in other types of deposits,wide ranges in temperature for each mineral assemblage in the studied VMS deposits can be interpreted as dropping temperatures as the hydrothermal activity was waning (lower temperature and increasingly feebler deep hydrothermal inputs) coupled with an increasing degree of entrainment of cooler unmodified seawater (e.g.,Wilkinson, 2001). $\delta^{34} \mathrm{~S}$ values of sulfides around $0 \%$ are generally assumed to reflect magmatic sources for sulfur. Such is the case for the distribution of data (Fig. 8) from the Copper King (Cyprus-type) and Rey de Plata (Kuroko-type) deposits (Miranda-Gasca, 1995; Miranda-Gasca et al., 2001) and, partly, La Minita and Tizapa-Santa Rosa (Kuroko-type). $\delta^{34} \mathrm{~S}$ values for sulfates from La Minita are very similar to those in sulfates in Albian-Cenomanian seawater (15 to 17\%o; Claypool et al., 1980). The temperatures of homogenization obtained in La Minita $\left(110^{\circ}\right.$ to $200{ }^{\circ} \mathrm{C}$ in barite mantos, and $140^{\circ}$ to $360{ }^{\circ} \mathrm{C}$ in other baritebearing assemblages) suggest that barite precipitation in this deposit was produced mostly from mixing between sulfate-rich seawater and upwelling hydrothermal fluids. Such feature is also found in subactual Kuroko-type seafloor vents (e.g., the Myojin Knoll in the Izu-Bonin arc; Iizasa et al., 1999). A similar behavior for $\delta^{34} \mathrm{~S}$ data is found at Rey de Plata (Miranda-Gasca, 1995; MirandaGasca et al., 2001). Rather contrastingly, the extremely low values obtained for sulfides in Campo Morado indicate that bacterial sulfate reduction occurred at the beginning of sulfide precipitation at the seafloor. Such process may account for most of the $\delta^{34} S$ values from the La Minita deposit as well. $\delta^{34} \mathrm{~S}$ values dominantly around $-5 \%$ in the Campo Morado and Tizapa-Santa Rosa deposits, with a significant concentration of values around $0 \%$ in the latter (also found in sulfides fromLaMinita), suggest that sulfur was derived from both magmatic and sedimentary or metasedimentary sources (i.e. leached from underlying sedimentary rocks). However, the modal distribution of values around 4.5 and $5 \%$ o found in the Cuale, El Rubí and Copper King deposits suggest that marine sulfate underwent thermal sulfate reduction (TSR) instead of bacterial sulfate reduction (BSR). In this subtype of VMS deposits, three main hypotheses have been set: (1) sulfur out of magmatic sources 
(Ishihara and Sasaki, 1978), either leached from underlying volcanic and volcaniclastic rocks or directly carried by upwelling magmatic fluids (Moss et al., 2001), (2) scavenging of sulfur out of seawater, or "seawater hydrothermal system", and (3) the "anhydrite buffer model" (Ohmoto et al., 1970; Kajiwara and Date, 1971; Ohmoto and Rye, 1979). The last two models assume that sulfate species carried in solution by seawater are fixed as anhydrite under the seafloor (a deep anhydrite layer), which would in turn be remobilized and the sulfur would be reduced to form sulfides, independently from the presence or lack of volcanic-volcaniclastic assemblages in the country rocks. Further analogies between the Cuale and El Rubí deposits and the "classical" Kuroko deposits in Japan are that both are hosted by acid volcanic rocks, and that the ores are found as stockworks and massive sulfide lenses in a proximal position to the exhalative centers (Charoy and GonzálezPartida, 1984). However, one of the main differences between them is that at Cuale and El Rubí the ore deposition is controlled by a more reducing environment (as suggested by the pyrite + pyrrhotite + sphalerite + chalcopyrite + cubanite association; González-Partida, 1985) than in the Kuroko deposits (with a dominant pyrite+chalcopyrite+bornite+hematite association; Sasaki, 1974), despite the traces of pyrrhotite and magnetite reported by Shimazaki (1974) in them. González-Partida (1985), upon geochemical models, determined that the ore-bearing fluids in Cuale and El Rubí were not reduced prior to ore deposition, and that the isotopic composition of the sources for sulfur in these deposits was about the same as the isotopic composition of sulfides $\left(\delta^{34} \mathrm{~S} \sim 5 \%\right.$ at Cuale, and $\sim 4.5 \%$ at El Rubí). Also, it is worth noting that the $\delta^{34} \mathrm{~S}$ values of sulfides in early stages of mineralization range from -3 to $-1.5 \%$. Thus, magmatic and seawater sulfur contributions varied through time and it is likely that the contribution of seawater and marine sulfate to ore-bearing fluidswas higher in early stages of mineralization than during the peaking stages of sulfide deposition, contrary to the possible magmatic sources for both fluids and sulfur. The volcano-sedimentary rocks that host the Cuale and El Rubí VMS deposits overlie carbonaceous metapelites (Fig. 4) that contain pyrite with $\delta^{34} \mathrm{~S}$ values that range from -2 to 8\%o (González-Partida, 1981). Such values are in accordance with the compositional range of $\delta^{34} \mathrm{~S}$ values ( -3 to $1 \%$ ) postulated by González-Partida (1985) in regional metapelites. As the Albian-Cenomanian seawater $\left(\delta^{34} \mathrm{~S}=15\right.$ to $17 \%$; Claypool et al., 1980) pervaded and upwelled into those, the isotopic composition of sulfides would have shifted towards 
increasingly higher values, and thus gypsum samples from late stages of mineralization at the El Rubí deposit exhibit $\delta^{34} \mathrm{~S}$ values at $\sim 22.6 \%$. Such feature suggests once more that the entrainment of unmodified seawater into mineralizing fluids increased as the paleohydrothermal systemwaned, which implied an increase in both $\mathrm{pH}$ and oxidation of ore-bearing fluids. This is reflected in mineral precipitation by a mineralogical shift from sulfiderich assemblages (pyrrhotite-stable) to sulfate assemblages (barite and gypsum) and to late hematite with Mn oxides and carbonates.

\section{Conclusions}

- VMS deposits and terrane boundaries. Most VMS deposits in Mexico occur close to terrane boundaries, i.e. (1) mostly within the southern half of the Guerrero composite terrane (GCT) along its eastern and costal boundaries but, interestingly, (2) also on the westernmost boundary of the continental margin of Oaxaquia (the San Ignacio deposit was thought to be associated with the GCT before this paper), (3) on the westernmost boundary of the Parral terrane, and (4) on the easternmost boundary of the Alisitos arc terrane. This feature is compatible with the majoritarian bearing of VMS deposits in submarine volcanosedimentary assemblages that formed in back-arc settings between the volcanic arcs and the continental margin of eastern Mexico, or within juvenile and slightly evolved arcs. That is so because some of the likeliest settings occurred, in most cases, by the boundaries of the different tectonostratigraphic terranes sitting along the western edge of the Proterozoic to Paleozoic basement rocks (namely, the Mixteco, Parral, Cortés and Caborca terranes, and Oaxaquia), where the hinterland and back-arc basins occurred. Then, such areaswould represent the frontal part of accreted terranes. No VMS deposits are known to occur in the northern half of the GCT (Tahue terrane), and this is explained by the fact that the widespread extensional unroofing did not propagate northwards at the extent that it did in the south.

- Exploration for VMS deposits. The exploration endeavor for VMS deposits has been traditionally focused on the southern half of the Guerrero composite terrane (GCT) and seems not permissive for its northern half. However, the new stratigraphic evidence for the San Ignacio deposit (see above) renders exploration for VMS deposits as favorable in the 
continentalmargin of Oaxaquia aswell. The potential for Paleozoic VMS deposits (e.g., the Besshi-type deposits at Teziutlán-Aire Libre, or the Kuroko-type deposits at Cerro Dolores, hosted by the Permo-Triassic Petlalcingo Group in the Mixteco terrane) is also a relevant topic for the Mexican metallogeny, but it is off the scope of this paper. Further, the close association of many VMS deposits thoughout Mexico with the borders between terranes that are not associated with Proterozoic to Paleozoic basements is a common feature and suggests some potential in similar settings, regardless ofwhether it occurswithin orwithout the GCT. It also follows fromthe above that exploration forMesozoic VMS deposits southwest from the GCT is unlikely, to say the least, unless such endeavor is focused on Central America, as indicated by the tectonicmodels and hypotheses by Carfantan (1981).

- Fluid inclusion and sulfur isotope studies in VMS deposits. Inclusion fluids from the studied VMS deposits span general ranges of salinities between 2.5 and $20 \mathrm{wt} \% \mathrm{NaCl}$ equiv., and temperatures of homogenization between $110^{\circ}$ and $420{ }^{\circ} \mathrm{C}$. In general, such thermocompositional span normally reflects the entrainment as mineralizing fluids of both seawater (unmodified and/or deeply circulated) and magmatic fluids. However, the highest temperature and salinity values occur distinctively in the stockwork of the Tizapa deposit ( $440^{\circ}$ to $550{ }^{\circ} \mathrm{C}, 39.7$ to 64.7 wt.\% NaCl, and 35.9 to 43.5 wt.\% KCl; González- Partida, 1984). When compared to similar temperature and salinity ranges in both VMS and recent seafloor hydrothermal vents, it is likely that such fluids reflect inputs of magmatic brines that exsolved from cooling shallow intrusives. In the Cuale and LaMinita deposits, thermal (Fig. 7), salinity and mineralogical zonations, which reflect an increase in oxidation and $\mathrm{pH}$ of mineralizing fluids with time, are explained as an increasing entrainment of seawater from the central part of paleohydrothermal systems outwards, and from climax to waning hydrothermal stages over time. Such process accounts for the observed evolution of fluids from the middle stages of mineralization (the hottest and more saline in each deposit), towards the last stages (where the most dilute and cooler fluids are found). $\delta^{34} \mathrm{~S}$ values for the studied VMS deposits reflect different sources of sulfur: magmatic, bacteriogenic, sedimentary-metasedimentary, and marine, in variable degrees of dominance of either source for each deposit and for each stage of mineralization. Seawater sulfate, in turn, could be reduced to sulfide by both bacterial and thermogenic processes. It is likely that the contribution of seawater and marine sulfate to mineralizing fluids in the Cuale and El Rubí 
depositswas higher in early stages of mineralization than during the peaking middle stages of sulfide deposition, whereas magmatic sources for both fluids and sulfur were the most important during middle stages. Then, for the studied deposits, (1) the increasing temperature and salinity from the early to the middle stageswould be reflecting an increasingmagmatic contribution for both fluids and sulfur, and (2) the waning of hydrothermal activity towards the last stages on mineralization would be the consequence of the invasion of the system by unmodified seawater as the outflow of upwelling deeply entrained fluids dwindled.

\section{Acknowledgments}

Financial support for this paper was obtained through the PAPIITUNAM (grant IN110810 to A. Camprubí), CONACYT (grant 155662 to A. Camprubí), and from the Dirección General de Investigación y Gestión del Plan Nacional I + D + i (grant CGL201020809 to P. Alfonso) programs. Additional funding was received from internal annual research budgets of the Instituto de Geología, Centro de Geociencias, and Instituto de Geofísica (UNAM).

\section{References}

Alfonso, P., Torró, L., Mesa, C., Parcerisa, D., Mata-Perelló, J.M., González-Partida, E., Canet, C., Garcia-Vallès, M., 2011. Mineralogical characterisation of the Tizapa ore deposit, Mexico. In: Barra, F., Reich, M., Campos, E., Tornos, F. (Eds.), 11th SGA Biennial Meeting - let's talk ore deposits 2. Ediciones Universidad Católica del Norte, Antofagasta, Chile, pp. 781-783.

Almazán-Vázquez, E., 1988a. Marco paleosedimentario y geodinámico de la Formación Alisitos en la Península de Baja California Norte. Rev. Inst. Geol. UNAM 7, 41-51.

Almazán-Vázquez, E., 1988b. Geoquímica de las rocas volcánicas de la Formación Alisitos del Arroyo La Bocana en el Estado de de Baja California Norte. Rev. Inst. Geol. UNAM 7, 7888. 
Barrie, C.D., Boyle, A.P., Cook, N.J., Prior, D.J., 2010. Pyrite deformation textures in themassive sulfide ore deposits of the Norwegian Caledonides. Tectonophysics 483, 269286.

Bendel, V., Fouquet, Y., Auzende, J.M., Lagabrille, Y., Grimaud, D., Urabe, T., 1993. The White Lady hydrothermal field, North Fiji back-arc basin, Southwest Pacific. Econ. Geol. 88, 2237-2249.

Binns, R.A., Scott, S.D., 1993. Actively forming polymetallic sulfide deposits associated with felsic volcanic rocks in the Eastern Manus back-arc basin, Papua New Guinea. Econ. Geol. 88, 2226-2236.

Bissig, T., Mortensen, J.K., Tosdal, R.M., Hall, B.V., 2008. The rhyolite-hosted VMS district of Cuale, Guerrero Terrane, west-central Mexico: silver-rich, base-metal mineralization emplaced in a shallow submarine continental margin setting. Econ. Geol. 103, 141-160.

Bodnar, R.J., 1993. Revised equation and table for determining the freezing point depression of H2O-NaCl solutions. Geochim. Cosmochim. Acta 57, 683-684.

Bodnar, R.J., Sterner, S.M., Hall, D.L., 1989. SALTY: A FORTRAN program to calculate compositions of fluid inclusions in the system $\mathrm{NaCl}-\mathrm{KCl}-\mathrm{H} 2 \mathrm{O}$. Comput. Geosci. 15, 1941.

Busby, C., Fackler Adams, B., Mattinson, J., Deoreo, S., 2006. View of an intact oceanic arc, from surficial to mesozonal levels: Cretaceous Alisitos arc, Baja California. J. Volcanol. Geotherm. Res. 149, 1-46.

Busby-Spera, C., 1988. Speculative tectonic model for the early Mesozoic arc of the southwest Cordilleran United States. Geology 16, 1121-1125.

Camprubí, A., 2009. Major metallogenic provinces and epochs of Mexico. SGA News 25, 1-20. Camprubí, A., 2013. Tectonic and metallogenic history of Mexico. In: Colpron, M., Bissig, T., Rusk, B.G., Thompson, J.F.H. (Eds.), Tectonics, metallogeny, and discovery: the North American Cordillera and similar accretionary settings. Society of Economic Geologists, Special Publication 17, pp. 201-243.

Camprubí, A., Albinson, T., 2007. Epithermal deposits in México - an update of current knowledge, and an empirical reclassification. In: Alaniz-Álvarez, S.A., Nieto-Samaniego, A.F. (Eds.), Geology of México: Celebrating the Centenary of the Geological Society of México. Geological Society of America Special Paper 422, pp. 377-415. 
Canet, C., Camprubí, A., González-Partida, E., Linares, C., Alfonso, P., Piñeiro-Fernández, J.F., Prol-Ledesma, R.M., 2009. Mineral assemblages of the Francisco I. Madero $\mathrm{Zn}-\mathrm{Cu}-\mathrm{Pb}-$ (Ag) deposit, Zacatecas, Mexico: implications for ore deposit genesis. Ore Geol. Rev. 35, 423-435.

Carfantan, J.C., 1981. Evolución estructural del Sureste de México; Paleogeografía e historia tectónica de las zonas internas Mesozoicas. Univ. Nac. Auton. Mex. Inst. Geol. Rev. 5, 207-216.

Carfantan, J.C., 1983. Les ensambles geológiques du Mexique Meridional; Evolution géodynamique durant le Mesozoïque et le Cenozoïque. Geofis. Int. 22, 9-37.

Centeno-García, E., Busby, C., Busby,M., Gehrels, G., 2011. Evolution of the Guerrero composite terrane along the Mexican margin, from extensional fringing arc to contractional continental arc. Geol. Soc. Am. Bull. 123, 1776-1797.

Charoy, B., González-Partida, E., 1984. Analyses des phases fluides associés a la genèse des amas sulfurés et des filons $\mathrm{Au}-\mathrm{Ag}$ de la province de Taxco-Guanajuato (Mexique). Bull. Mineral. 107, 285-305.

Clark, K.F., Fitch, D.C., 2009. Evolución de depósitos metálicos en tiempo y espacio en México. In: Clark, K.F., Salas-Pizá, G., Cubillas-Estrada, R. (Eds.), Geología Económica de México, 2nd edition Servicio Geológico Mexicano- Asociación de Ingenieros de Minas, Metalurgistas y Geólogos de México, pp. 62-133.

Claypool, G.E., Holser, W., Kaplan, I.R., Sakai, H., Zák, I., 1980. The age curve of sulfur and oxygen isotopes in marine sulfate and their mutual interpretation. Chem. Geol. 28, 199260.

Cooke, D.R., Bull, S.W., Large, R.R., McGoldrick, P.J., 2000. The Importance of oxidized brines for the formation of Australian Proterozoic stratiform sediment-hosted $\mathrm{Pb}-\mathrm{Zn}$ (Sedex) deposits. Econ. Geol. 95, 1-18.

Crawford, M.L., 1981. Phase equilibria in aqueous fluid solutions. Mineral. Assoc. Canada Short Course Ser. 6, 75-100.

Davis, D.W., Lowenstein, T.K., Spencer, R.J., 1990. The melting behavior of fluid inclusions in laboratory-grown halite crystals in the systems $\mathrm{NaCl}-\mathrm{H} 2 \mathrm{O}, \mathrm{NaCl}-\mathrm{KCl}-\mathrm{H} 2 \mathrm{O}, \mathrm{NaCl}-$ $\mathrm{MgCl} 2-\mathrm{H} 2 \mathrm{O}$ and $\mathrm{NaCl}-\mathrm{CaCl} 2-\mathrm{H} 2 \mathrm{O}$. Geochim. Cosmochim. Acta 54, 591-601. 
de Ronde, C.E.J., 1995. Fluid chemistry and isotopic characteristics of sea-floor hydrothermal systems and associated VMS deposits: potential for magmatic contributions. Mineral. Assoc. Canada Short Course 23, 479-511.

Escalona-Alcázar, F.J., Delgado-Argote, L.A., Weber, B., Núñez-Peña, E.P., Valencia, V.A., Ortiz-Acevedo, O., 2009. Kinematics and U-Pb dating of detrital zircons from the Sierra de Zacatecas, Mexico. Rev. Mex. Cienc. Geol. 26, 48-64.

Fouquet, Y., Stackeleberg, U., Charlou, J.L., Erzinger, P.M., Mühe, R., Wiedickee, M., 1993. Metallogenesis in back-arc environments: the Lau Basin example. Econ. Geol. 88, 21542181.

Franklin, J.M., 1996. Volcanic-associatedmassive sulphide basemetals. In: Eckstrand, O.R., Sinclair,W.D., Thorpe, R.I. (Eds.), Geology of Canadian mineral deposit types. Geological Survey of Canada, Geology of Canada 8, pp. 158-183.

Franklin, J.M., Gibson, H.L., Jonasson, I.R., Galley, A.G., 2005. Volcanogenic massive sulfide deposits. In: Hedenquist, J.W., Thompson, J.F.H., Goldfarb, R.J., Richards, J.P. (Eds.), Economic Geology 100th Anniversary Volume. Society of Economic Geologists, Littleton CO, pp. 523-560.

Giggenbach,W.F., 1992a. Magma degassing and mineral deposition in hydrothermal systems along convergent plate boundaries. Econ. Geol. 87, 1927-1944.

Giggenbach,W.F., 1992b. Isotopic shifts in waters from geothermal and volcanic systems along convergent plate boundaries and their origin. Earth Planet. Sci. Lett. 113, 495-510.

Goldhammer, R.K., Johnson, C.A., 2001. Middle Jurassic-Upper Cretaceous paleogeographic evolution and sequence-stratigraphic framework of the northwest Gulf of México rim. In: Bartolini, R., Buffler, T., Cantú-Chapa, A. (Eds.), The western Gulf of México basin: tectonics, sedimentary basins, and petoleum systems. AAPG Memoir 75, pp. 45-81.

Góngora-Flemate, D., 2001. Francisco I. Madero; a sedex-type deposit? Unpublished MSc dissertation, Queen's University, Kingston, Ontario, Canada, 59 pp.

González-Partida, E., 1981. La province filonienne Au-Ag de Taxco-Guanajuato (Mexique) (Thèse docteur-ingeneur), INPL Nancy, France (172 pp.).

González-Partida, E., 1984. Análisis de las inclusiones fluidas e isótopos de azufre, hidrógeno y oxígeno de los sulfuros masivos de Tizapa-Sta Rosa, Edo. de México. Geomimet 128, 66- 
76. González-Partida, E., 1985. Étude métallogénique de la partie centre-occidentale du Mexique (Thèse de Doctorat d'État), INPL Nancy, France (472 pp.).

González-Partida, E., 1993. Datos geoquímicos de roca total para la secuencia volcanosedimentaria Cretácica en Cuale-El Rubí, Jalisco, y Tierra Caliente, Guerrero, México. Geofis. Int. 32, 249-259.

González-Partida, E., Torres-Rodríguez, V., 1988. Evolución tectónica de la porción centrooccidental de México y su relación con los yacimientos minerales asociados. Geofis. Int. 27, 543-581.

González-Villalvaso, L., López-Soto, R., 2009. Geología del yacimiento Madero, Zacatecas, México. In: Clark, K.F., Salas-Pizá, G., Cubillas-Estrada, R. (Eds.), Geología económica de México, $2^{\text {a }}$ edición Servicio Geológico Mexicano - asociación de Ingenieros de Minas, Metalurgistas y Geólogos de México, pp. 902-909.

Hall, B.V., Gómez-Torres, P.P., 2000a. Geology of the Kuroko-type massive sulphide deposits of the Cuale district, Jalisco state, Mexico. In: Sherlock, R.L., Logan, M.A.V. (Eds.), Volcanogenic Massive Sulphide Deposits of Latin America. Geological Association of Canada Special Publication 2, pp. 141-162.

Hall, B.V., Gómez-Torres, P.P., 2000b. The El Gordo volcanogenicmassive sulphide deposit, Leon-Guanajuato district, Central Mexico. In: Sherlock, R.L., Logan, M.A.V. (Eds.), Volcanogenic Massive Sulphide Deposits of Latin America. Geological Association of Canada Special Publication 2, pp. 163-166.

Hall, B.V., Gómez-Torres, P.P., 2000c. Geology and exploration of the Los Gavilanes deposit, Leon, Mexico - a bimodal-siliciclastic volcanogenic massive sulphide deposit. In: Sherlock, R.L., Logan, M.A.V. (Eds.), Volcanogenic Massive Sulphide Deposits of Latin America. Geological Association of Canada Special Publication 2, pp. 167-182.

Hannington, M.D., de Ronde, C.E.J., Petersen, S., 2005. Sea-floor tectonics and submarine hydrothermal systems. In: Hedenquist, J.W., Thompson, J.F.H., Goldfarb, R.J., Richards, J.P. (Eds.), Economic Geology 100th Anniversary Volume. Society of Economic Geologists, Littleton CO, pp. 111-141.

Hayes, S.K., 1996. Epidotization of the sheeted dike-plutonic contact, Troodos ophiolite, Cyprus. 9th Keck Symposium Volume, Williams Collegepp. 221-224. 
Herzig, P.M., Hannington, M.D., Fouquet, Y., Stacklberg, U.V., Petersen, S., 1993. Gold-rich polymetallic sulfides from the Lau back arc and implications for the geochemistry of gold in sea-floor hydrothermal systems of the Southwest Pacific. Econ. Geol. 88, 2182-2209.

Iizasa, K., Fiske, R.S., Ishizuka, O., Yuasa, M., Hashimoto, J., Ishibashi, J., Naka, J., Horii, Y., Fujiwara, Y., Imal, A., Koyama, S., 1999. A Kuroko-type polymetallic sulfide deposit in a submarine silicic caldera. Science 283, 975-977.

Ioannou, S.E., Spooner, E.T.C., Barrie, C.T., 2007. Fluid temperature and salinity characteristics of the Matagami volcanogenic massive sulfide district, Quebec. Econ. Geol. 102, 691-715.

Ishihara, S., Sasaki, A., 1978. Sulfur of Kuroko deposits - a deep seated origin? Mining Geol. 28, 361-367. Johnson, B.J., Monte-Martínez, J.A., Canela-Barboza, M., 2000. Geology of the San Nicolás deposit, Zacatecas, Mexico. Geol. Assoc. Can. Spec. Publ. 2, 71-85.

Kajiwara, Y., Date, J., 1971. Sulfur isotope study of Kuroko-type and Kieslager-type, stratabound massive sulfide deposits in Japan. Geochem. J. 1, 133-150.

Kelley, D.S., Delaney, J.R., 1987. Two-phase separation and fracturing in mid ocean ridge gabbros at temperatures greater than $700{ }^{\circ} \mathrm{C}$. Earth Planet. Sci. Lett. 83, 53-66.

Kelley, D.S., Robinson, P.T., 1990. Development of a brine-dominated hydrothermal system at temperatures of $400-500{ }^{\circ} \mathrm{C}$ in the upper level putonic sequence, Troodos ophiolite, Cyprus. Geochim. Cosmochim. Acta 54, 653-661.

Kelley, D.S., Robinson, P.T., Malpas, J.G., 1992. Processes of brine generation and circulation in the oceanic crust: fluid inclusion evidence from the Troodos ophiolite, Cyprus. J. Geophys. Res. 97, 9,307-9,322.

Keppie, J.D., Nance, R.D., Fernández-Suárez, J., Storey, C.D., Jeffries, T.E.,Murphy, J.B., 2006. Detrital zircon data from the eastern Mixteca terrane, southern Mexico: evidence for an Ordovician-Mississippian continental rise and a Permo-Triassic clastic wedge adjacent to Oaxaquia. Int. Geol. Rev. 48, 97-111.

Klesse, E., 1968. Geology of the El Ocotito-Ixcuinatoyac region and of La Dicha stratiform sulphide deposit, state of Guerrero. Bol. Soc. Geol. Mex. 31, 107-140.

Lapierre, H.,Bosch,D., Dupuis, V.,Polvé,M.,2000. Multiple plume events in the genesis of the peri-Caribbean Cretaceous oceanic plateau province. J. Geophys. Res. 105, 8403-8421.

Large, R.R., 1992. Australian volcanic-hostedmassive sulfide deposits: features, styles, and genetic models. Econ. Geol. 87, 469-510. 
Lewis, P.W., Rhys, D.A., 2000. Geological setting of the Tizapa volcanogenic massive sulphide deposit, Mexico State, Mexico. In: Sherlock, R.L., Logan, M.A.V. (Eds.), Volcanogenic Massive Sulphide Deposits of Latin America. Geological Association of Canada Special Publication 2, pp. 87-112.

Lorinczi, G.I., Miranda, J.C., 1978. Geology of the massive sulfide deposits of Campo Morado, Guerrero, México. Econ. Geol. 73, 180-191.

Macías, C., Solís, G., 1985. Mineragrafía, microtermometría e isotopía de algunos yacimientos del distrito minero de Cuale, Jalisco. Unpublished BSc dissertation, Universidad Nacional Autónoma de México, Distrito Federal, Mexico, 129 pp.

Martínez-Reyes, J., Vassallo-Morales, L.F., Franco-Ibarra, F.J., 1995. Geología y potencial minero de la porción central-poniente del Estado de Guanajuato: La zona de la exreserva minera "Leon-Guanajuato", Instituto de Geología, UNAM, and Dirección de promoción minera. Secretaria de Economía del Estado de Guanajuato (65 pp.).

Martini, M., Mori, L., Solari, L., Centeno-García, E., 2011. Sandstone provenance of the Arperos Basin (Sierra de Guanajuato, central Mexico): Late Jurassic-Early Cretaceous back-arc spreading as the foundation of the Guerrero terrane. J. Geol. 119, 597-617.

Martini, M., Fitz, E., Solari, L., Camprubí, A., Hudleston, P.J., Lawton, T.F., Tolson, G., Centeno-García, E., 2012. The Late Cretaceous evolution of the Mexican Fold-Thrust Belt and its possible relationship to the accretion of the Guerrero Terrane. In: Aranda-Gómez, J.J., Tolson, G., Molina-Garza, R.S. (Eds.), The southern Cordillera and beyond. The Geological Society of America Field Trip 25, pp. 20-38.

Mengelle-López, J.J., 2009. Microtermometría e isótopos de $\delta^{34} \mathrm{~S}$ del cuerpo de sulfuros masivos Los Mexicanos, al SE de la Sierra de Guanajuato. Actas INAGEQ 15, 81-82.

Mengelle-López, J.J., Picazo-Alba, M.A., Canet, C., Camprubí, A., Prol-Ledesma, R.M., 2006. Depósitos VMS de la Cuenca La Esperanza, Guanajuato. Bol. Mineral. 17, 11-12.

Mengelle-López, J.J., Canet, C., Prol-Ledesma, R.M., González-Partida, E., Camprubí, A., 2013. Secuencia vulcano-sedimentaria La Esperanza (Cretácico Inferior) al norte de Guanajuato, México: importancia en la exploración de sulfuros masivos vulcanogénicos. Bol. Soc. Geol. Mex. 65, 511-525. 
Miranda-Gasca,M.A., 1995. The volcanogenicmassive sulfide and sedimentary exhalative deposits of the Guerrero terrane,Mexico. Unpublished $\mathrm{PhD}$ dissertation, University of Arizona, Tucson, Arizona, USA, 205 pp.

Miranda-Gasca, M.A., 2000. The metallic ore-deposits of the Guerrero Terrane, western Mexico: an overview. J. S. Am. Earth Sci. 13, 403-413.

Miranda-Gasca, M.A., 2003. The volcanogenic massive sulfide deposits of Mexico. Proceedings of the 99th Annual Meeting, Cordilleran Section, Geological Society of America, paper 241.

Miranda-Gasca, M.A., de la Garza, V., Téllez, R., Hernández, A., 2001. The Rey de Plata Cretaceous $\mathrm{Zn}-\mathrm{Pb}-\mathrm{Cu}-\mathrm{Ag}-\mathrm{Au}$ volcanogenic massive sulfide deposit, Guerrero, Mexico. Soc. Econ. Geol. Spec. Publ. 8, 277-290.

Monter-Ramírez, A., Zavala-Esquivel, A., 2011. Contribución a la geología del yacimiento VMS Rey de Plata, Teloloapan, Gro. In: Corona-Esquivel, R., Gómez-Caballero, J.A. (Eds.), Acta de Sesiones XXIX Convención Internacional de Minería Acapulco, Guerrero. Asociación de Ingenieros de Minas, Metalurgistas y Geólogos de México, pp. 159-165.

Mortensen, J.K., Hall, B.V., Bissig, T., Friedman, R.M., Danielson, T., Oliver, J., Rhys, D.A., Ross, K.V., Gabites, J.E., 2008. Age and paleotectonic setting of volcanogenic massive sulfide deposits in the Guerrero Terrane of Central Mexico: constraints from $\mathrm{U}-\mathrm{Pb}$ age and $\mathrm{Pb}$ isotope studies. Econ. Geol. 103, 117-140.

Moss, R., Scott, S.D., Binns, R., 2001. Gold content of Eastern Manus Basin volcanic rocks: implications for enrichment in associated hydrothermal precipitates. Econ. Geol. 96, 91107.

Nehlig, P., 1991. Salinity of oceanic hydrothermal fluids: a fluid inclusion study. Earth Planet. Sci. Lett. 102, 310-325.

Nieto-Samaniego, A.F., Alaniz-Álvarez, S.A., Camprubí, A., 2005. La Mesa Central deMéxico: estratigrafía, estructura y evolución tectónica cenozoica. Bol. Soc. Geol. Mex. 57, 285-318. Nieto-Samaniego, A.F., Alaniz-Álvarez, S.A., Camprubí, A., 2007. The Central Mesa of México: stratigraphy, structure and tectonic evolution during the Cenozoic. In: AlanizÁlvarez, S.A., Nieto-Samaniego, A.F. (Eds.), Geology ofMéxico: Celebrating the Centenary of the Geological Society of México. Geological Society of America Special Paper 422, pp. 41-70. 
Ohmoto, H., Rye, R., 1979. Isotopes of sulfur and carbon. In: Barnes, H.L. (Ed.), Geochemistry of hydrothermal ore Deposits, second edition John Wiley and Sons, New York, pp. 509567.

Ohmoto, H., Skinner, B., 1983. The Kuroko and related volcanogenic massive sulfide deposits: introduction and summary of new findings. In: Ohmoto, H., Skinner, B. (Eds.), The Kuroko deposits. Economic Geology Monography 5, pp. 1-8.

Ohmoto, H., Kajiwara, Y., Date, J., 1970. The Kuroko ores in Japan, products of seawater. Geol. Soc. Am. Bull. 2, 640-651.

Oliver, J., Payne, J., Rebagliati, M., Cluff, R., 2000. Precious-metal-bearing volcanogenic massive sulphide deposits, Campo Morado, Guerrero, Mexico. In: Sherlock, R.L., Logan, M.A.V. (Eds.), Volcanogenic Massive Sulphide Deposits of Latin America. Geological Association of Canada Special Publication 2, pp. 57-69.

Oliver, J., Payne, J., Kilby, D., Rebagliati, M., 2001. Lower Cretaceous precious metal-rich volcanogenic massive sulfide deposits, Campo Morado, Guerrero, Mexico. Soc. Econ. Geol. Spec. Publ. 8, 265-276.

Ortiz-Hernández, L.E., Chiodi, M., Lapierre, H., Monod, O., Calvet, P., 1992. El arco intraoceánico alóctono (cretácico inferior) de Guanajuato-características petrográficas, geoquímicas, estructurales e isotópicas del complejo filoniano y de las lavas basálticas asociadas: Implicaciones geodinámicas. Rev. Inst. Geol. UNAM 9, 126-145.

Ortiz-Hernández, L.E., Escamilla-Casas, J.C., Flores-Castro, K., Ramírez-Cardona, M., Acevedo-Sandoval, O., 2006. Características geológicas y potencial metalogenético de los principales complejos ultramáficos-máficos de México. Bol. Soc. Geol. Mex. 57, 161-181.

Pesquera, A., Velasco, F., 1993. Ore metamorphism in sulfide mineralizations from the Cinco Villas massif (Western Pyrenees, Spain). Econ. Geol. 88, 266-282.

Petersen, E.U., 2000. Geology and geochemistry of the Oxec, Cyprus-type VMS deposit, Guatemala. In: Sherlock, R.L., Logan, M.A. (Eds.), Volcanogenic massive sulphide deposits of Latin America. Geological Association of Canada Special Publication 2, pp. 277-291.

Pindell, J., Kennan, L., 2001. Kinematic evolution of the Gulf of Mexico and Caribbean. In: Bartolini, R., Buffler, T., Cantú-Chapa, A. (Eds.), The western Gulf of México Basin: 
tectonics, sedimentary basins, and petoleumsystems. American Association of Petroleum Geologists Memoir 75, pp. 1-27.

Pisutha-Arnond, V., Ohmoto, H., 1983. Thermal history, and chemical and isotopic compositions of the ore-forming fluids responsible for the Kuroko massive sulfide deposits in the Hokuroku district of Japan. In: Ohmoto, H., Skinner, B.J. (Eds.), The Kuroko and related volcanogenic massive sulfide deposits. Economic Geology Monograph 5, pp. 523558.

Precejus, P.H.B., Märten, A., 1993. Geology and mineralogy of massive sulfide ores from the Central Okinawa Trough, Japan. Econ. Geol. 88, 2210-2225.

Ramírez-Espinoza, J., 2001. Tectonomagmatic evolution of the Paleozoic Acatlán complex in southern Mexico, and its correlation with the Appalachian system. Unpublished PhD dissertation, University of Arizona, Tucson, Arizona, USA, 170 pp.

Rhys, D.A., Enns, S.G., Ross, K.V., 2000. Geologucal setting of deformed VMS-type mineralization in the Azulaquez-Tlanilpa area, northern Guerrero State,Mexico. In: Sherlock, R.L., Logan, M.A.V. (Eds.), Volcanogenic Massive Sulphide Deposits of Latin America. Geological Association of Canada Special Publication 2, pp. 113-133.

Rubinovich-Kogan, R., 1988. Mineralogía y paragénesis del depósito de sulfuros masivos sinsedimentarios La Esmeralda, Estado de México. Unpublished MSc dissertation, Facultad de Ciencias, Universidad Nacional Autónoma de México, Distrito Federal, Mexico, 147 pp.

Sasaki, A., 1974. Isotopic data of Kuroko deposits. Soc. Mining Geol. Japan Spec. Issue 6, 389397. Sato, T., 1972. Behaviour of ore-forming solutions in seawater. Mining Geol. 22, 3142.

Shimazaki, Y., 1974. Ore minerals of the Kuroko-type deposits. Soc. Mining Geol. Japan Spec. Issue 6, 311-322. Stakes, D.S., Vanko, D.A., 1986. Multistage hydrothermal alteration of gabbroic rocks from the failed Mathematician Ridge. Earth Planet. Sci. Lett. 79, 75-92.

Sterner, S.M., Hall,D.L., Bodnar, R.J., 1988. Synthetic fluid inclusions. V. Solubility relations in the system $\mathrm{NaCl}-\mathrm{KCl}-\mathrm{H} 2 \mathrm{O}$ under vapor-saturated conditions. Geochim. Cosmochim. Acta 52, 989-1005.

Talavera-Mendoza, O., 2001. Mélanges in southern Mexico: geochemistry and metamorphism of Las Ollas complex (Guerrero terrane). Can. J. Earth Sci. 37, 1309-1320. 
Talavera-Mendoza, O., Ruiz, J., Gehrels, G.E., Valencia, V.A., Centeno-García, E., 2007. Detrital zircon $\mathrm{U} / \mathrm{Pb}$ geochronology of southern Guerrero and western Mixteca arc successions (southernMexico): Newinsights for the tectonic evolution of the southwestern North America during the late Mesozoic. Geol. Soc. Am. Bull. 119, 1052-1065.

Tardy, M., Lapierre, H., Freydier, C., Coulon, C., Gill, J.B., Mercier De Lépinay, B., Beck, C., Martínez, J., Talavera-Mendoza, O., Ortiz, E., Stein, G., Bourdier, J.L., Yta, M., 1994. The Guerrero suspect terrane (western Mexico) and coeval arc terranes (the Greater Antilles and the Western Cordillera of Colombia): a late Mesozoic intra-oceanic arc accreted to cratonal America during the Cretaceous. Tectonophysics 230, 49-73.

Taylor, B.E., 1992. Degassing of H2O from rhyolite magma during eruption and shallow intrusion, and the isotopic composition of magmatic water in hydrothermal systems. Rep. Geol. Surv. Japan 279, 190-194.

Torró, L., Alfonso, P., González-Partida, E., Canet, C., Gómez-Fernández, F., 2011. Preliminary study of fluid inclusions and sulphur isotopes of the Tizapa ore deposit, Mexico. In: Barra, F., Reich, M., Campos, E., Tornos, F. (Eds.), 11th SGA Biennial Meeting — let's talk ore deposits 2. Ediciones Universidad Católica del Norte, Antofagasta, Chile, pp. 775-777.

Vanko, D.A., Laverne, C., 1998. Hydrothermal anorthitization of plagioclase within the magmatic/hydrothermal transition at mid-ocean ridges: examples from deep sheeted dikes (Hole 504B, Costa Rica Rift) and a sheeted dike root zone (Oman ophiolite). Earth Planet. Sci. Lett. 162, 27-43. Vanko, D.A., Stakes, D.S., 1991. Fluids in oceanic layer 3: evidence from veined rocks, Hole 735B, southwest Indian Ridge. In: Von Herzen, R.P., Robinson, P.T., et al. (Eds.), Proceedings of the Ocean Drilling Program. Scientific Results 118, pp. $181-215$.

Vanko, D.A., Griffith, J.D., Erickson, C.L., 1992. Calcium-rich brines and other hydrothermal fluid inclusions from plutonic rocks, Oceanographer Transform, Mid-Atlantic Ridge. Geochim. Cosmochim. Acta 56, 35-47.

Wilkinson, J.J., 2001. Fluid inclusions in hydrothermal ore deposits. Lithos 55, 229-272. Yta, M., Moreno-Tovar, R., Cardona-Patiño, F., Córdoba-Méndez, D., 2003. Contribución a la definición de superposición de eventos metalogénicos en el yacimiento de Francisco I. Madero. Rev. Mex. Cienc. Geol. 20, 124-132. 
Zamora-Vega, O., 2004. Los sulfuros masivos volcanogenéticos de Tizapa, Zacazonapan, Edo. de México, ¿un yacimiento tipo Kuroko?: Datos geoquímicos, mineragráficos y microtermométricos. Unpublished MSc dissertation, Posgrado en Ciencias de la Tierra, Universidad Nacional Autónoma de México, México D.F. 


\section{FIGURE CAPTIONS}

Figure 1. Distribution of ore deposits formed from the Triassic to the Early Cretaceous in the Pacific convergent margin of Mexico, showing terrane names and other significant geological features. Modified from Camprubí (2009). See available ages in Camprubí (2013). The deposit names that carry the "und. age" label stand for those deposits whose age is undetermined but reasonably inferred fromtheir stratigraphic position or bearing according to various sources,mostly found inMiranda-Gasca (2000) and in OrtizHernández et al. (2006). The position of the Baja California Peninsula is reconstructed to its approximate pre-rifting position. Paleotectonic reconstructions from this period were taken from Centeno-García et al. (2011). Following these, the area of Jurassic-Albian arc undergoing synvolcanic extensional unroofing (green) is extended northwards into known similar areas, and the Jurassic-Albian back-arc basin is extended southwards into the Petatlán-Papanoa region, as data from the Loma Baya deposit (this paper, see sections below) confirm that it formed in suprasubduction-zone back-arc ophiolites. Thick gray dashed lines denote terrane boundaries. Symbols for ore deposit types are the same as in Camprubí (2009, 2013), and gray symbols and the labels for types of ore deposits in the legend stand for those absent in this period.

Figure 2. $\mathrm{Cu}, \mathrm{Pb}$ and $\mathrm{Zn}$ metal associations (Large, 1992) in Mexican VMS deposits considering their terrane distribution.

Figure 3. Representative geological cross-sections of the Campo Morado, Rey de Plata (Guerrero) and Tizapa (State of México) VMS deposits in the Guerrero composite terrane. Redrawn from Oliver et al. (2000), Miranda-Gasca et al. (2001), and Lewis and Rhys (2000), respectively. Similar lithological units in either deposits are indicated by the same or similar colors, as of Fig. 4. Characteristic lithologies and ore bodies, with their location indicated in the cross-sections are featured in pictures (a) to (f). (a) Hand specimen of metalutites and metasandstones of the Lower Cretaceous Miahuantepec Formation, Rey de Plata deposit. (b) Massive pyrite with chalcopyrite from the base of the Tehuixtla body, Rey de Plata deposit. (c) Chalcopyrite, galena and silvermineral (associatedwith the galena) assemblage in a deep quartz vein, Tizapa deposit. (d) Small- 
scale folding and crenulation in carbonaceous shales of the Cretaceous Amatepec Formation, in drill-core samples, Tizapa deposit. (e) Barely deformed massive sulfides, with sphalerite-rich (dark brown) and pyrite-rich layers (golden), showing some supergene oxidation, Tizapa deposit. (f) Small-scale folding, including ptygmatic folding in relatively incompetent layers, in sphalerite- (brown) and galena-rich (metallic gray) massive sulfides intercalatedwith chert layers, showing remobilized galena towards fold hinge cores and pyrite into cracks in differentially competent chert layes, Tizapa deposit. Abbreviations: $\mathrm{cpy}=$ chalcopyrite, $\mathrm{cv}=$ covellite (due to slight supergene oxidation), $\mathrm{ga}=$ galena, $\mathrm{py}=$ pyrite, $\mathrm{qz}=$ quartz .

Figure 4. Geological model for the Cuale (Jalisco) and palinspastic restoration for the Tizapa (state of México) VMS deposits. Redrawn from Bissig et al. (2008) and Lewis and Rhys (2000), respectively. Similar lithological units in either deposit are indicated by the same or similar colors, as of Fig. 3.

Figure 5. Photographs of the La Minita VMS deposit in Michoacán. (a) "Tail" of the stratiform deposits (lenses) showing its general stratigrapy, with the massive barite-rich bodies at the bottom, iron-oxide and Mn-hydroxide silicified bodies on top (b), and veinlets (stockwork?) with barite and sulfides underneath, developed on carbonate rocks (d). (c) Replacement of host carbonate rocks by siderite (matrix) and barite (rudist fossils). (e) Photomicrograph of sphalerite and barite spheres from the massive bodies under plain polarized light. (f) Pervasively chloritized host volcanic tuffwithmineralization of barite aggregates in a hand specimen (about 20 cmwide). (g) General view of the thickest exposed portion of themassive barite lens in the main open pit; the height of the cliff is about $20 \mathrm{~m}$. The diameter of the coin in picture is $2 \mathrm{~cm}$. Abbreviations: $\mathrm{ba}=$ barite, $\mathrm{sp}=$ sphalerite .

Figure 6. Photomicrographs fromthe Tizapa VMS deposit, State ofMéxico. (a)Muscovite displays a lepidoblastic arrangement around a quartz aggregate, which ismost likely secondary after pre-tectonicmineral assemblage; thin section, crossed polars. (b) Aspect of crenulated schists (D3): there is evidence for pressure-solution cutting a quartzmuscovite aggregate, remnant from earlier bands; thin section, crossed polars. (c) Muscovite crystals showing a decussated texture suggestive of contact metamorphism; 
thin section, crossed polars. (d) Chalcopyrite filling intergranular spaces between euhedral pyrite crystals accompanied by sphalerite showing chalcopyrite disease, and galena; polished section, plain reflected light. (e) Aspect of an unidentified sulphosalt filling intergranular spaces between subhedral-euhedral pyrite crystals; chalcopyrite and sphalerite replace locally pyrite; polished section, plain reflected light. (f) Late galena filling microfractures and partially replacing pyrite and chalcopyrite which occurs filling intergranular spaces among subhedral-euhedral pyrite crystals; polished section, plain reflected light. Abbreviations: $\mathrm{cpy}=$ chalcopyrite; $\mathrm{ga}=$ galena; $\mathrm{py}=$ pyrite; $\mathrm{qz}=$ quartz; $\mathrm{sp}$ $=$ sphalerite; uss $=$ unidentified sulfosalt .

Figure 7. Above: Correlation between salinity and temperature of homogenization data of fluid inclusions fromthe Cuale (red), El Rubí (yellow), La Minita (navy blue), Campo Morado (purple) and Tizapa (green)VMS deposits. Data for each deposit are positioned according to average temperature and salinity values, and blue bars display the span for each variable. Symbols are coded according to the host mineral and style ofmineralization (stockwork or stratiform). These data are compared with those frompresent-day VMS and Kuroko-type deposits, and Mississippi Valley-type or MVT deposits (Wilkinson, 2001), with thermocompositional fields I, IIa, IIb and III that, according to Sato (1972), represent four types of hydrothermal fluids associated withVMS deposits. Type-I fluids are low-temperature and denser than evolved seawater,whereas types II and III are less dense than evolved seawater and relatively high-temperature. The equilibriumbetween seawater and upwelling hydrothermal fluids allows density changes, and ratios between suchwater sources indicate proximal to distal positions to the feeder zones for ore precipitation (faults and/or stockwork zones). Data for the high-temperature and high-salinity fluid inclusion assemblage of Tizapa and the accompanying picture of an example of a fluid inclusion of such assemblage were taken fromGonzález-Partida (1984). Also featured are the data ranges reported by MirandaGasca (1995) and Miranda-Gasca et al. (2001), and Mengelle-López (2009) for the Rey de Plata (light blue) and San Ignacio (pink) deposits (no further indication of average values or ore associationwas given by such authors), respectively. Below: Ranges of salinity and temperature of homogenization data of fluid inclusions for the considered deposits, and separate distribution of data for each in the thermocompositional field 
defined formineralizing fluids in Mexican VMS deposits (lower right)with the approximate evolution in time ofmineralizing fluids, when available from the deposit zonation.

Figure 8. Histogramof new $\delta^{34} \mathrm{SCDT}$ data for sulfides and sulfates in selectedMexican VMS deposits for this study. See data in Table 2. The data from Tizapa were taken from González-Partida (1984) and Torró et al. (2011) and include new determinations (although this study is still in progress), and the data from Rey de Plata were taken from Miranda-Gasca (1995). 
Fig. 1

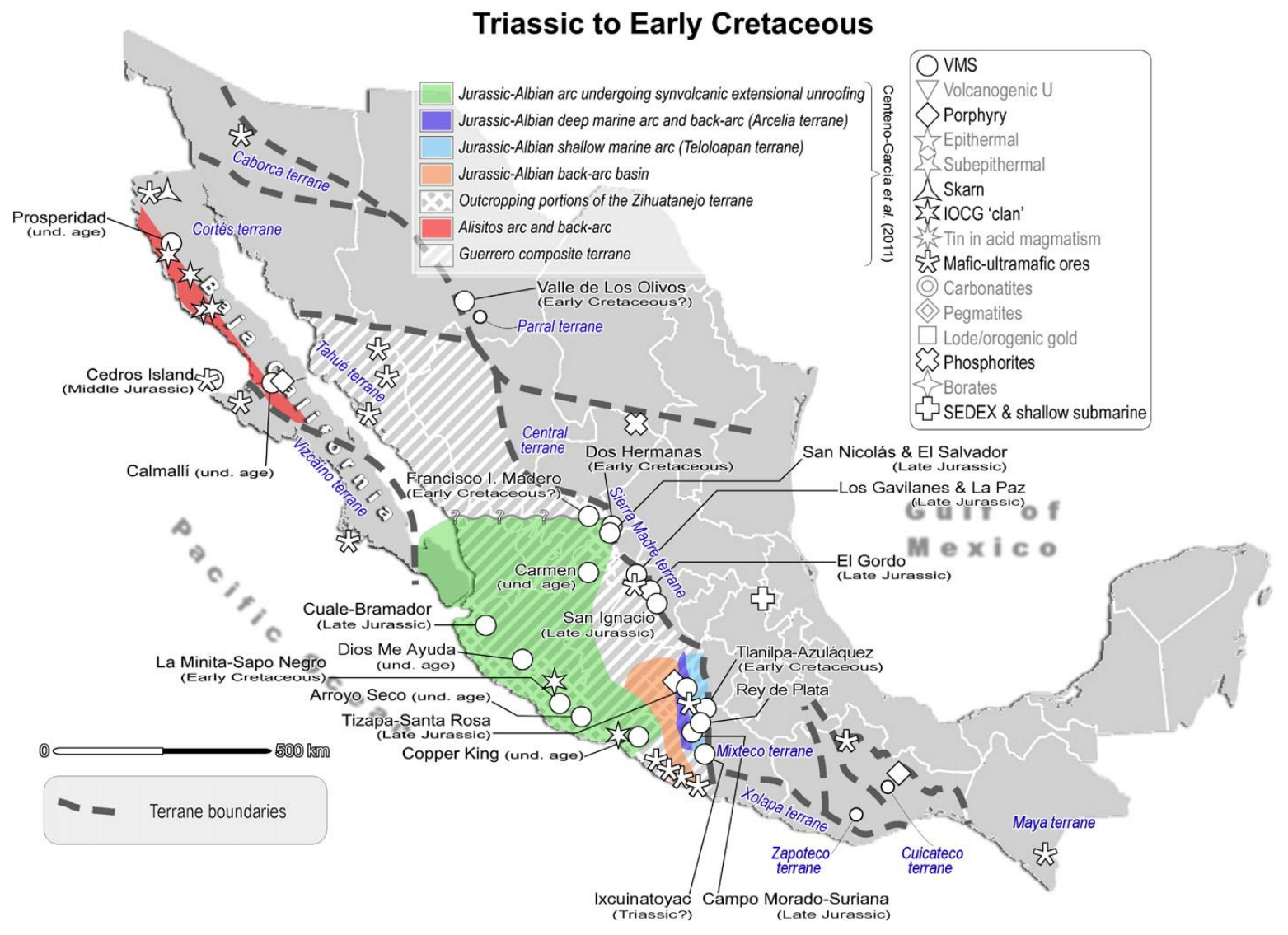

Fig. 2

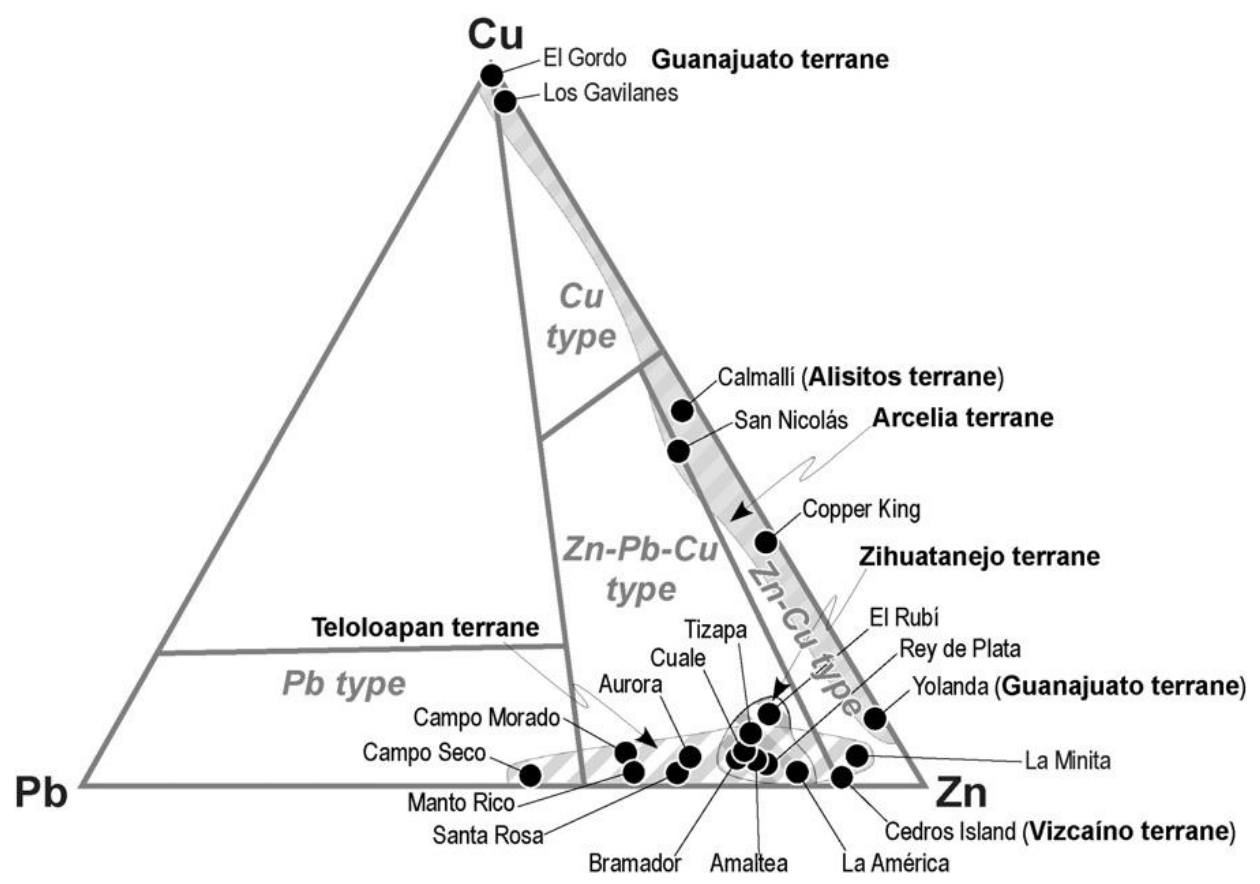


Fig. 3
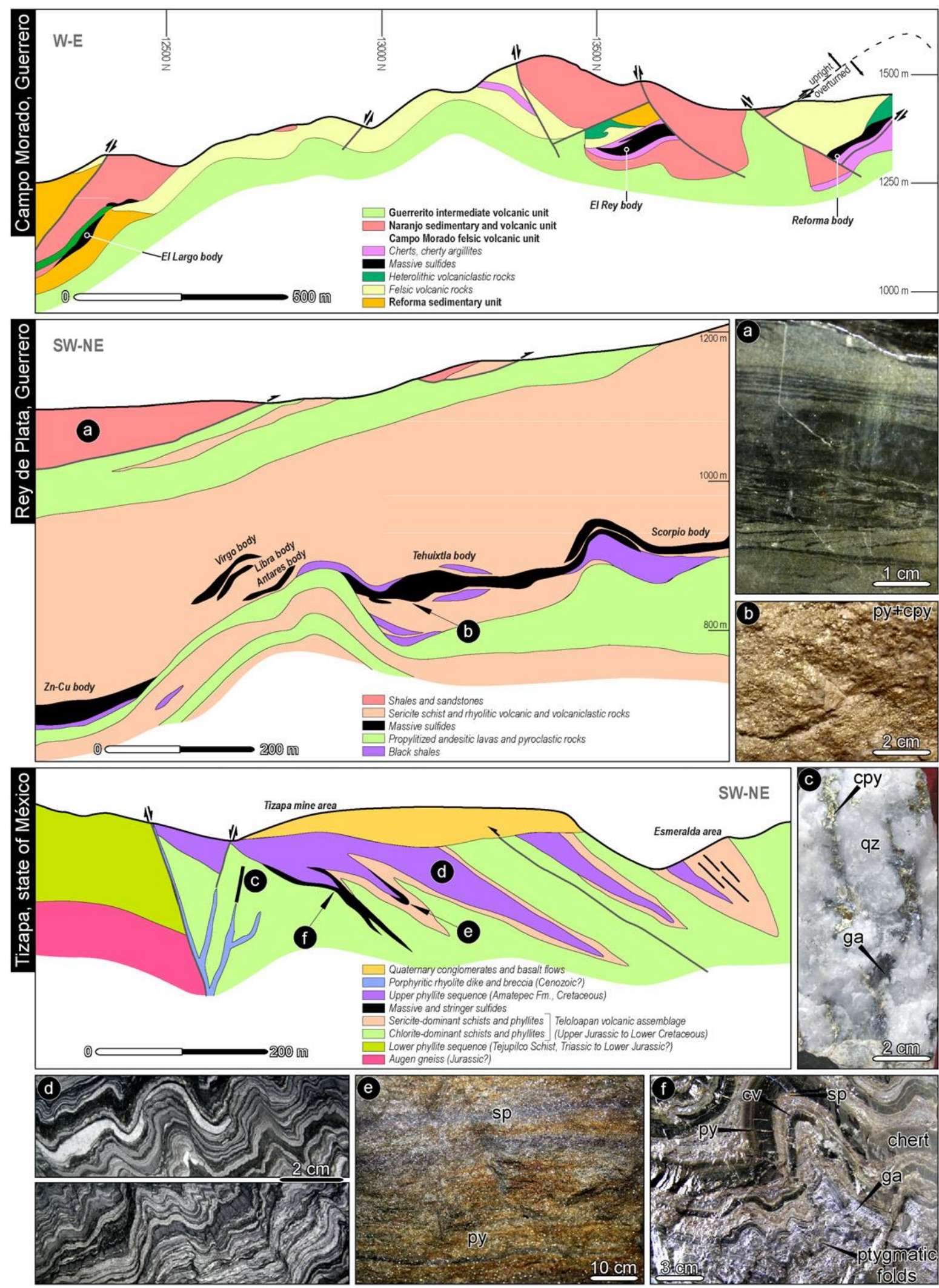
Fig 4

\section{Cuale, Jalisco}
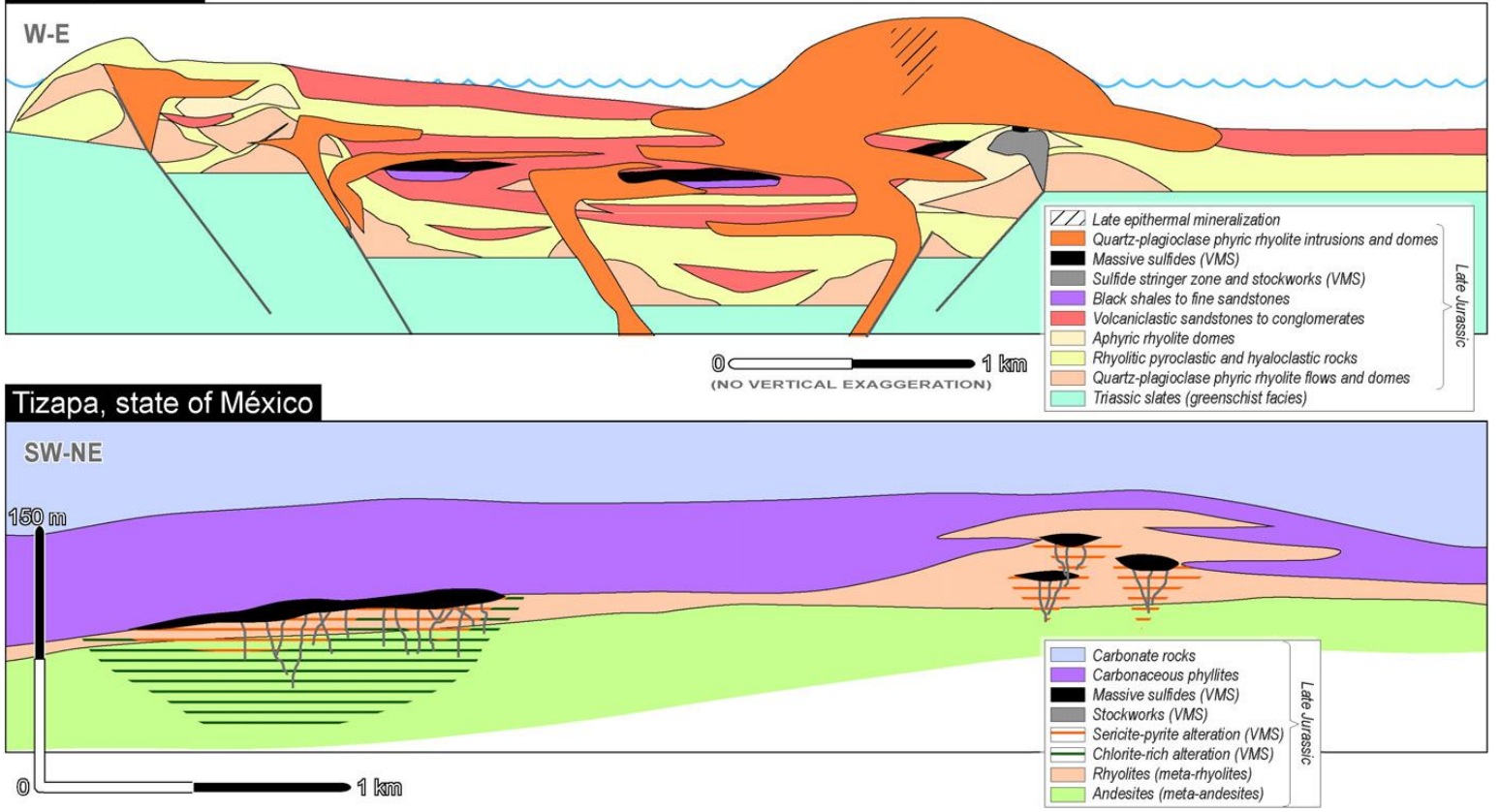
Fig. 5

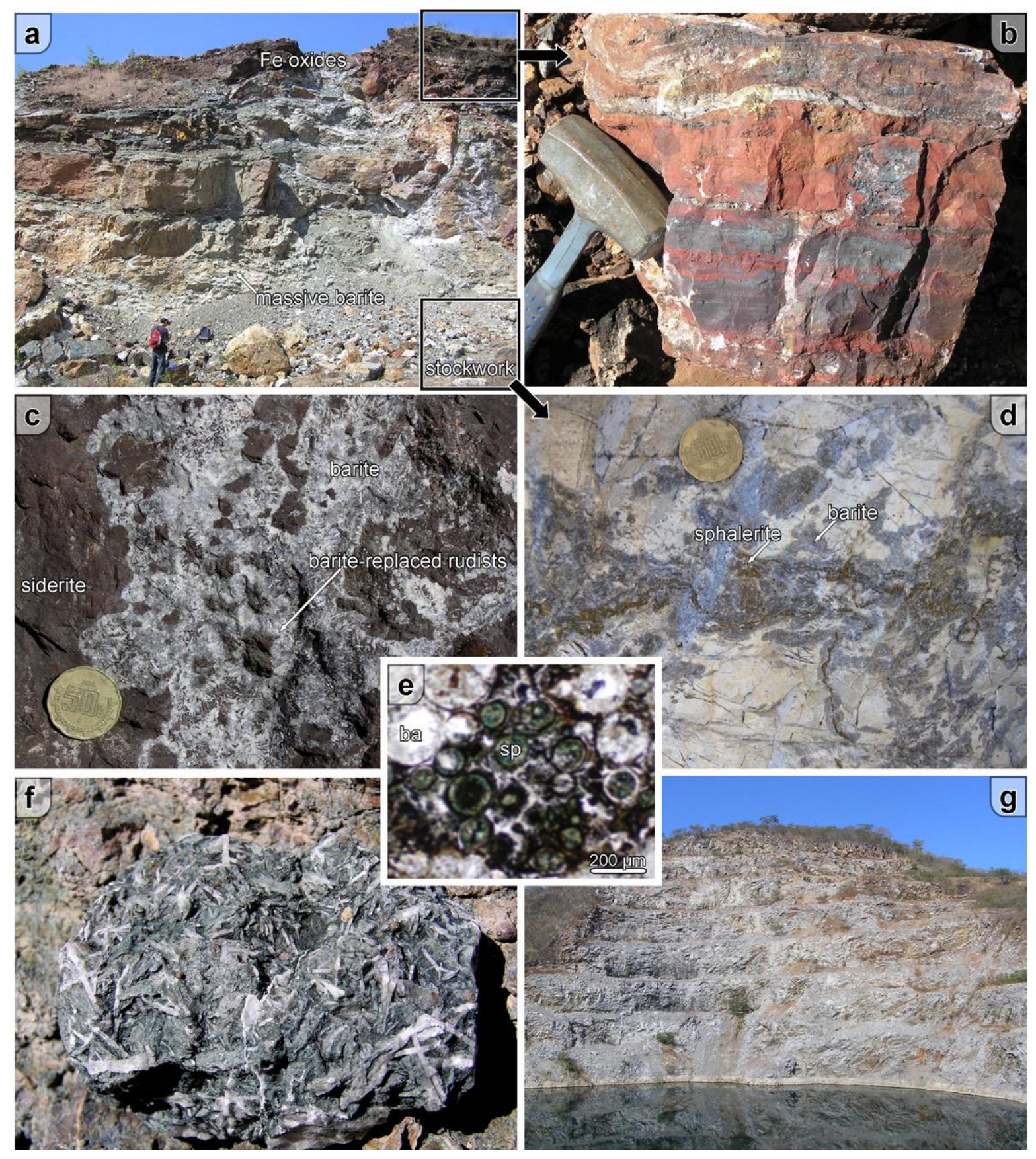


Fig. 6

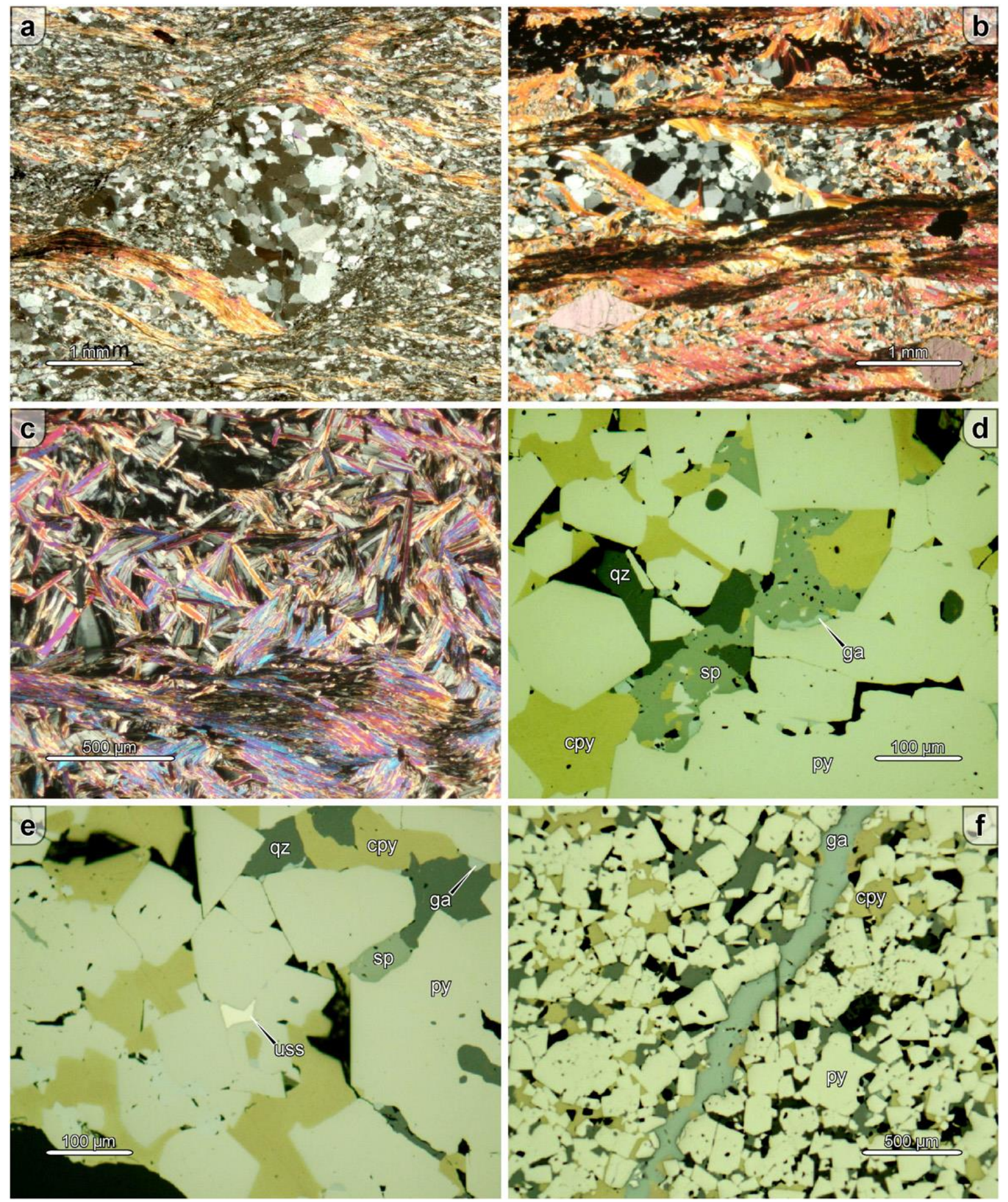


Fig. 7

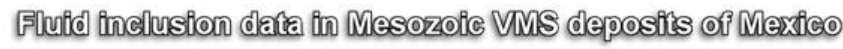

\section{Salinity-Th correlation}
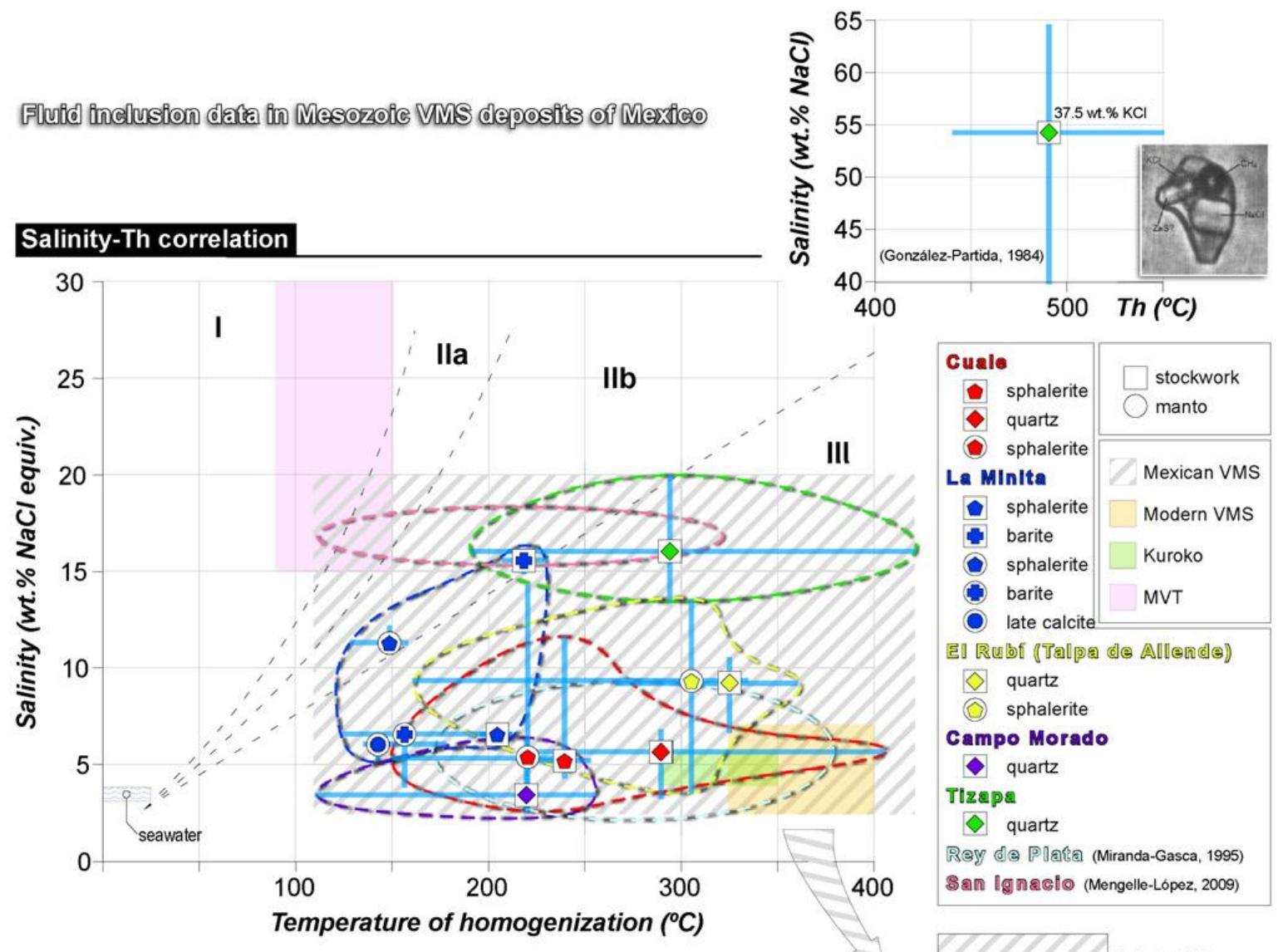

Ranges of salinity \& Th

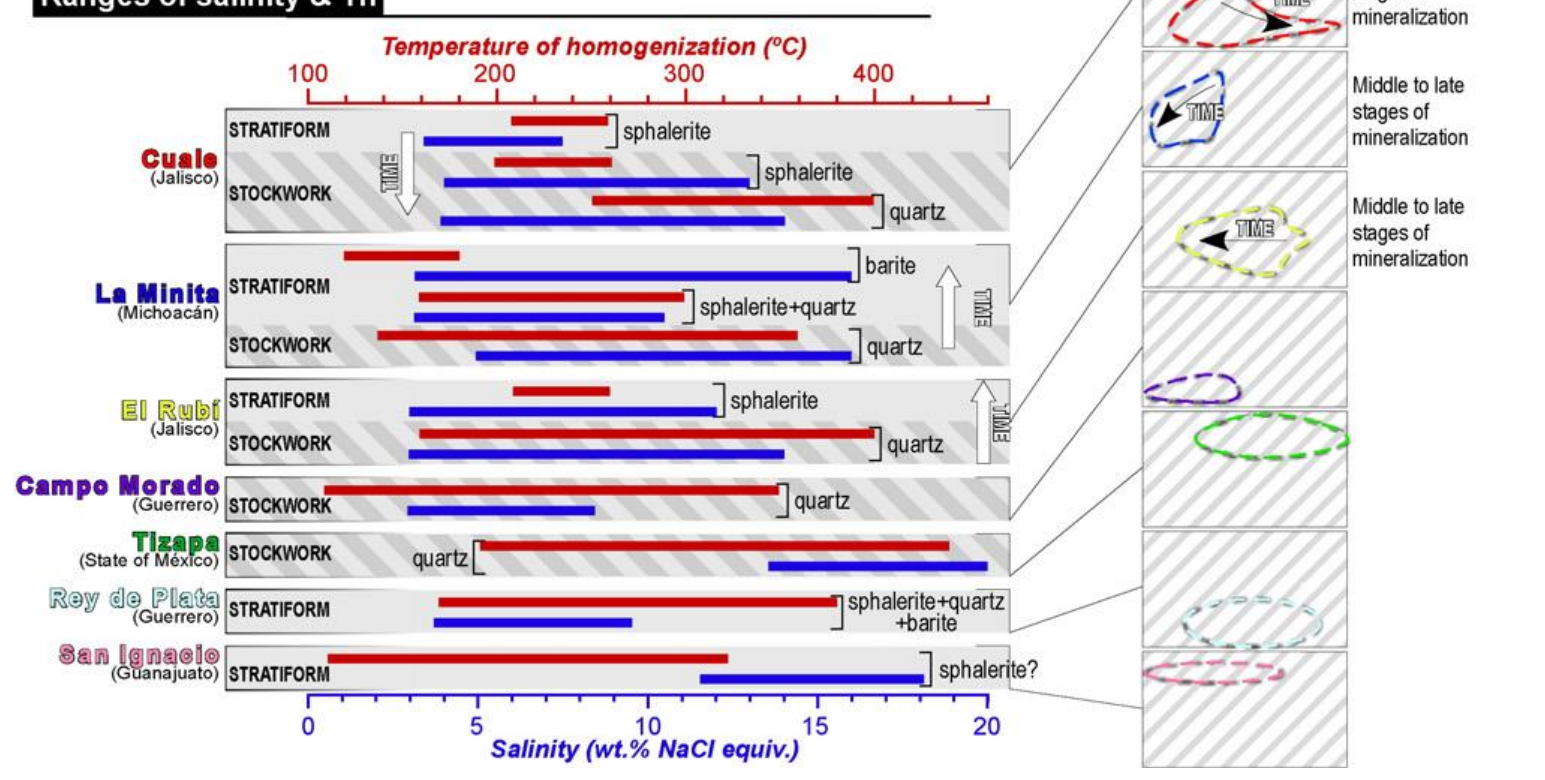


Fig. 8

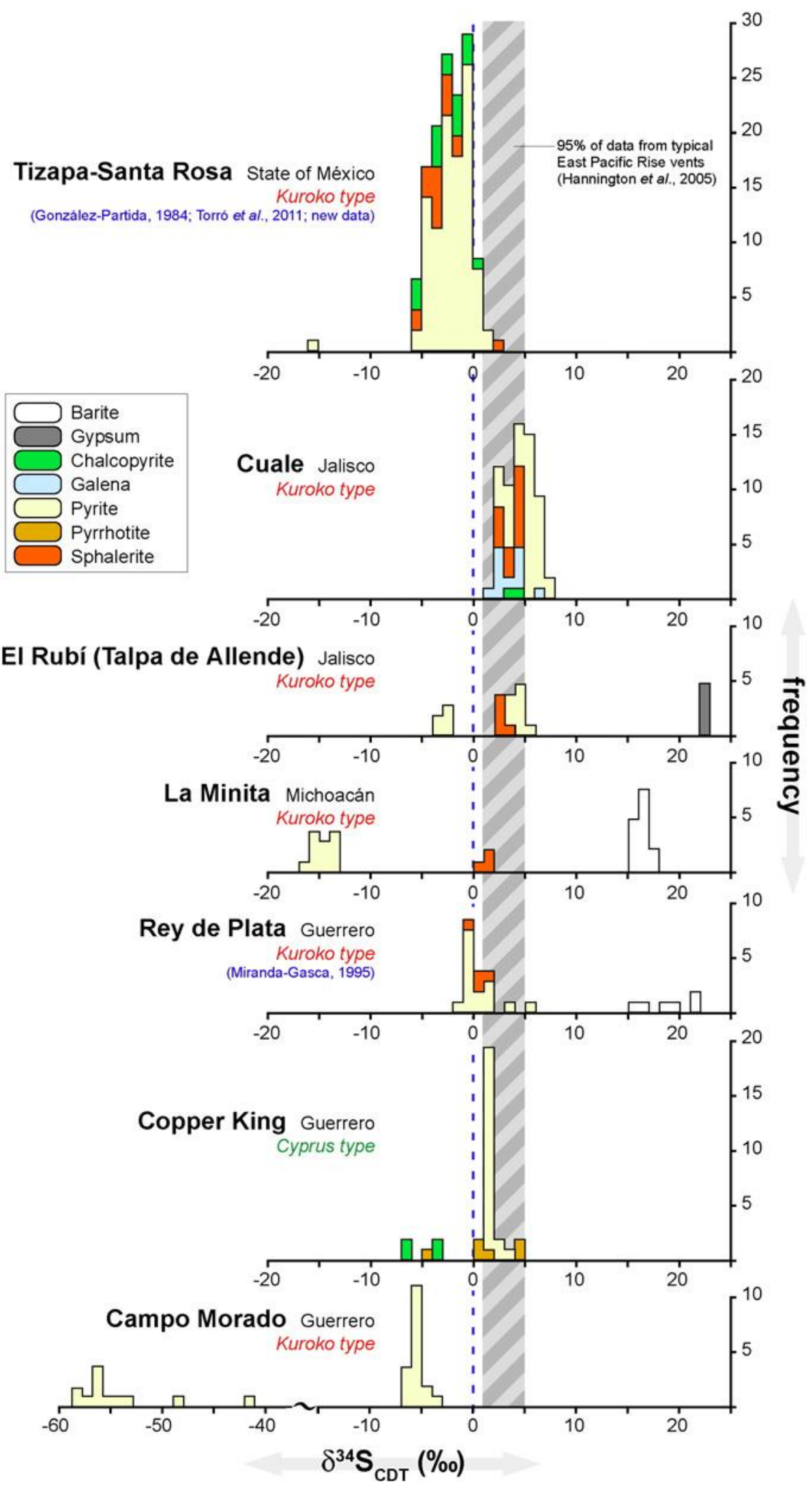

